\title{
REVIEW
}

\section{Primary atopic disorders}

\author{
Jonathan J. Lyons (D) and Joshua D. Milner (D)
}

\begin{abstract}
Monogenic disorders have provided fundamental insights into human immunity and the pathogenesis of allergic diseases. The pathways identified as critical in the development of atopy range from focal defects in immune cells and epithelial barrier function to global changes in metabolism. A major goal of studying heritable single-gene disorders that lead to severe clinical allergic diseases is to identify fundamental pathways leading to hypersensitivity that can be targeted to provide novel therapeutic strategies for patients with allergic diseases, syndromic and nonsyndromic alike. Here, we review known single-gene disorders leading to severe allergic phenotypes in humans, discuss how the revealed pathways fit within our current understanding of the atopic diathesis, and propose how some pathways might be targeted for therapeutic benefit.
\end{abstract}

\section{Introduction}

The study of monogenic causes for primary immunodeficiency diseases (PIDDs) has provided a number of important conceptual advances in our understanding of immune system function in host defense and has led to identification of discrete pathways required for protection against specific microbial pathogens. A number of these disorders have comorbid phenotypes associated with type 2 or allergic effector responses as part of the clinical spectrum of disease (Fig. 1; Table 1). Monogenic disorders have also been described in which allergic phenotypes are discrete and do not present with immunodeficiency. These disorders have proven invaluable as they have identified pathways that can specifically promote allergic phenotypes, some of which are unique to humans, and have provided important insights into the pathogenesis of allergy.

Atopy, derived from the Greek words with the same root meaning "unusual" or "out of place," was first invoked by Arthur F. Coca and Robert A. Cooke to denote the strangeness of allergic disease, specifically hay fever and asthma, and referred to both the dominant heritability of such a predisposition and the presence of symptoms "against non-precipitogenic substances as well as against precipitogenic substances” (Coca and Cooke, 1923). Soon this term began to be used interchangeably with clinical allergic disease, despite Cooke maintaining that the term was meant to "indicate and specify the familial or hereditary group of the spontaneously appearing allergies in man" (Cooke, 1947). In 1963 Gell and Coombs, proposed an updated classification of allergic phenomenon where atopy and anaphylaxis were grouped together as type I immediate hypersensitivity, a nomenclature which continues in use today (Gell and Coombs, 1963). In doing so, the concept of immediate hypersensitivity irrespective of the presence of "precipitogen," now recognized as IgE, as proposed with the original concept of atopy, was lost, while aspects of heritability were retained. Currently the Nomenclature Review Committee of the World Allergy Organization/European Academy of Allergy and Clinical Immunology defines atopy as a tendency to become sensitized and express IgE to environmental allergens after "ordinary exposure" (Johansson et al., 2004). However, since shortly after inception, there has been debate over the appropriate use of the term (Spector and Farr, 1976) and calls for the user to clearly define their intending meaning of the term atopy if used (Nelson, 2013).

In the context of monogenic disorders leading to allergic inflammation, the term atopy, specifically invoking the original intended meaning of heritable symptoms of immediate hypersensitivity regardless of foreign antigen dependence, is a particularly well-suited descriptive term. Because the atopic diathesis is distinct from immunodeficient, autoimmune, or autoinflammatory phenotypes ascribed to other monogenic diseases of the immune system, and in the spirit of Coca and Cooke, we would propose the term "primary atopic disorders" to classify heritable genetic disorders which present with deregulated pathogenic allergic effector responses irrespective of sensitization. These include genetic disorders leading to hives and other consequences of abnormal mast cell degranulation, chronic type $2 \mathrm{~T}$ helper (Th2)- and eosinophil-mediated allergic inflammation, and exuberant IgE production. In this review, we will describe how specific lesions affecting adaptive immune cells, mast cells, and epithelial barrier proteins can promote the allergic phenotypes observed in these syndromes.

Laboratory of Allergic Diseases, National Institute of Allergy and Infectious Diseases, National Institutes of Health, Bethesda, MD.

Correspondence to Joshua D. Milner: jdmilner@niaid.nih.gov.

This is a work of the U.S. Government and is not subject to copyright protection in the United States. Foreign copyrights may apply. This article is distributed under the terms of an Attribution-Noncommercial-Share Alike-No Mirror Sites license for the first six months after the publication date (see http://www.rupress.org/terms/). After six months it is available under a Creative Commons License (Attribution-Noncommercial-Share Alike 4.0 International license, as described at https://creativecommons.org/ licenses/by-nc-sa/4.0/). 


\section{ßJEM}

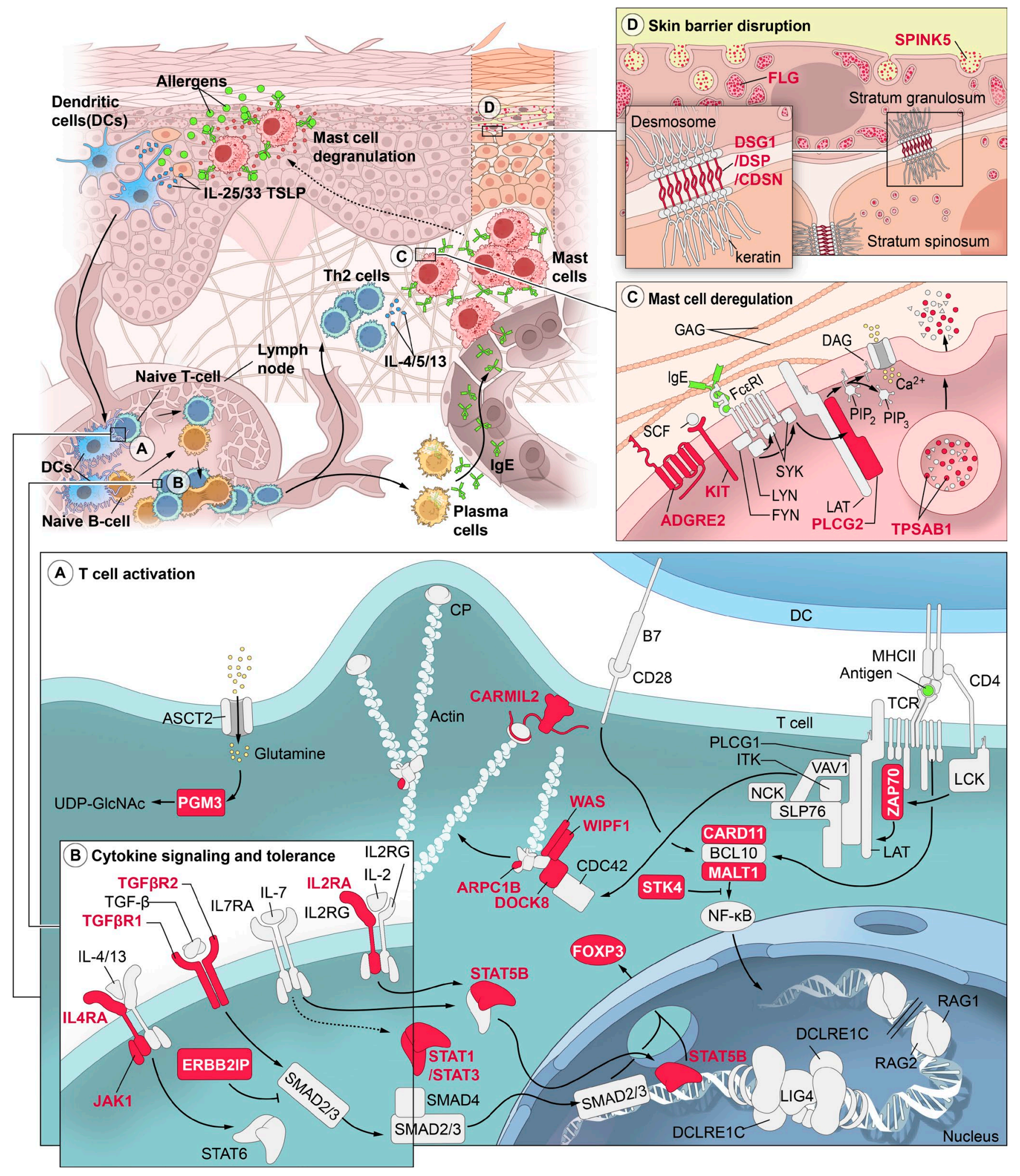

Figure 1. Schematic of genetic mutations leading to primary atopic disorders. (Top left) A simplified schema for allergic sensitization and reactivity displays inappropriate transcutaneous exposure of immune cells to exogenous allergen as a result of impaired epithelial barrier function. Subsequent activation of epithelial cells leads to expression of IL-25, IL-33, and thymic stromal lymphopoeitin (TSLP), which primes the allergic response. (A) Activated dendritic cells migrate to skin draining lymph nodes, where they present antigen in the context of $\mathrm{MHCll}$ to naive $\mathrm{CD} 4^{+} \mathrm{T}$ cells. The pMHC complex is recognized by the TCR complex, which leads to cellular activation. During T cell activation, a number of intracellular events occur, in which mutations leading to impaired activation, proliferation, cytoskeletal remodeling, and/or fitness (shown in red) promote allergic phenotypes in humans (see the corresponding text for detailed descriptions of known functions and pathological results of all mutations in this figure). In addition to TCR-dependent signals, the cytokine milieu during and 


\section{Impaired TCR signaling and cytoskeletal remodeling}

A number of mouse studies have demonstrated that although strong TCR peptide-MHC (pMHC) interactions promote Th1 or Th17 differentiation, low-avidity interactions promote Th2 skewing of naive $\mathrm{CD}^{+} \mathrm{T}$ cells during differentiation (Constant and Bottomly, 1997; Yamane and Paul, 2013). This has been demonstrated elegantly through transgenic TCR-based peptide models in vitro (Hosken et al., 1995; Tao et al., 1997; Jorritsma et al., 2003), using low doses of randomly synthesized peptides in naive human $\mathrm{T}$ cell differentiation cultures (Barber et al., 2013) and in vivo mouse studies (van Panhuys et al., 2014). In addition, a number of mouse models generated with germline mutations in molecules critical to the TCR signaling cascade, including zeta chain of $\mathrm{T}$ cell receptor-associated protein kinase 70 (Zap70), linker for activation of $\mathrm{T}$ cells ( Lat), caspase recruitment domain family, member 11 (Card11), and others, have demonstrated a strong bias toward Th2 phenotypes in vivo (Jun et al., 2003; Jakob et al., 2008; Mingueneau et al., 2009). In humans, most mutations in pathways critical for propagation of TCR signals were first reported in the context of recessive severe combined immunodeficiencies (SCID; Arpaia et al., 1994; Chan et al., 1994; Elder et al., 1994; Greil et al., 2013; Jabara et al., 2013; Stepensky et al., 2013; Punwani et al., 2015; Keller et al., 2016; Bacchelli et al., 2017); both the severe clinical phenotypes and the mode of inheritance likely contributed to their early identification in this context. Because formation of functional $\mathrm{T}$ cells was altogether lost in these individuals, the potential consequences of these lesions on $\mathrm{T}$ helper phenotypes could not be evaluated.

However, as additional patients with intermediate phenotypes have undergone genetic sequencing, hypomorphic mutations in many of these pathways have been identified with distinct atopic consequences (Table 1). Although most ZAP70 mutant patients develop SCID, some with protein-positive mutations have heterogeneous presentations, including a severe Th2 diathesis (Arpaia et al., 1994; Chan et al., 1994; Elder et al., 1994; Picard et al., 2009; Turul et al., 2009). Further downstream of the TCR and ZAP70 is the CARD11-B cell chronic lymphocytic leukemia/lymphoma 10 (BCL10)-mucosa-associated lymphoid tissue lymphoma translocation gene 1 (MALT1; CBM) complex that propagates signals both through NF- $\kappa$ B and mTOR pathways (Bertin et al., 2001; Hamilton et al., 2014). This signalosome creates an essential molecular node between proximal TCR signals and transcription factor activation. Biallelic loss-of-function mutations in all three of these molecules have been described to result in combined immunodeficiency with variable numbers of T lymphocytes (Greil et al.,
2013; Jabara et al., 2013; Stepensky et al., 2013; Torres et al., 2014; Punwani et al., 2015). More recently, hypomorphic and dominant negative mutations in CARD11 have shown to result in moderate to severe atopic dermatitis and associated elevations in IgE, with many patients also exhibiting susceptibility to infection (Dadi et al., 2017; Ma et al., 2017a). Hypomorphic heterozygous mutations in MALT1 have likewise been reported to result in severe atopic dermatitis and elevated IgE (McKinnon et al., 2014). Impairment in NF- $\kappa$ B pathway activation and $\mathrm{T}$ cell proliferation in vitro was observed in both cases, and with CARD11 mutations, mTORC1 activation of S6-kinase was similarly impaired.

After $\mathrm{T}$ cell activation and propagation of early signals, substantial repetitive cytoskeletal rearrangement is required to facilitate the massive clonal expansion that occurs in response to antigen stimulation in vivo. To accomplish this, Wiskott-Aldrich syndrome protein (WASP), which at resting state is autoinhibited and stabilized by WASP-interacting protein (WIP), must be activated by Phospholipase C-gamma (PLCY)-derived phosphatidylinositol 4,5-bisphosphate (PIP2) and cell division cycle 42 (CDC42; Zigmond, 2000). Once this occurs, WASP is released by WIP to associate with the actin-related protein (ARP) $2 / 3$ complex, enabling actin assembly to commence, thus enabling cellular migration and proliferation.

A large number of null mutations in WAS have now been shown to lead to the classical presentation of the Wiskott-Aldrich syndrome, which includes severe atopic dermatitis, thrombocytopenia, and combined immunodeficiency (Ochs, 2009). In addition to allergic skin disease, these patients have recently been shown to have increased sensitization and clinical allergy to food antigens (Lexmond et al., 2016). Hypomorphic and activating mutations have been associated with a spectrum of hematologic diseases including X-linked thrombocytopenia (XLT) and neutropenia, respectively. XLT patients also appear to have increased prevalence of sensitization to food allergens and food allergy relative to the general population, albeit less than Wiskott-Aldrich syndrome patients (Lexmond et al., 2016), suggesting that although the mutations are insufficient to drive other features of the Wiskott-Aldrich syndrome, sufficient impairment may exist to promote allergic disease. Furthermore, a null homozygous mutation in WAS/WASL-interacting protein family member 1 (WIPF1) encoding WIP, which abolished WASP expression, was reported to phenocopy classical WAS patients (Lanzi et al., 2012), as have homozygous loss-of-function mutations in the gene encoding an ARP2/3 subunit, ARP 2/3 complex subunit 1B (ARPC1B; Kahr et al., 2017; Kuijpers et al., 2017; Somech et al., 2017).

shortly after TCR engagement is critical in determining the effector fate of $C D 4^{+} T$ cells. (B) Mutations in several cytokine receptors and associated signaling molecules in JAK-STAT pathways (shown in red) are associated with allergic phenotypes. (A and $\mathbf{B}$ ) In addition to enhanced Th2 skewing and promotion of IgE-class switching of B cells, these mutations may affect TGF- $\beta$ and IL-2 signaling or their transcriptional target FOXP3 and impair CD4 ${ }^{+}$T reg formation and/ or stability, thereby disrupting peripheral tolerance. After this priming event, tissue-resident mast cells in the periphery (top left) take up secreted IgE and express this on their surface, bound to the high-affinity IgE receptor (FcERI) awaiting reexposure to allergen, which ultimately leads to receptor cross-linking and degranulation. (C) Mutations in mast cell molecules that alter reactivity, proliferation, and secretory protein composition are associated with primary atopic disorders (shown in red). (D) Finally, although Th2-associated inflammation can disrupt skin barrier integrity, a number of mutations in genes restricted to the epithelium have been shown to likewise impair barrier function and promote allergic phenotypes in the same manner. Genes in which mutations have been reported (LIG4, DCLRE1C, ILTRA, IL2RG, and RAGI/2) in association with Omenn syndrome are also included (A) for completeness; mutations in ADA and $C H D 7$, as well as 22q11 deletions, which can also promote this strongly Th2-skewed inflammatory state, are not depicted. 
Table 1. Genetic mutations associated with primary atopic disorders.

\begin{tabular}{|c|c|}
\hline Altered process & Genes \\
\hline $\begin{array}{l}\text { Impaired TCR signaling and } \\
\text { cytoskeletal remodeling }\end{array}$ & $\begin{array}{l}\text { ZAP70, CARD11, MALT1, WAS, WIPF1, } \\
\text { ARPC1B, DOCK8, CARMIL2 }\end{array}$ \\
\hline Altered cytokine signaling & $\begin{array}{l}\text { STAT3 }{ }^{D N}, S T A T 1^{G O F}, S T A T 5 B^{L O F}, S T A T 5 B^{G O F} \text {, } \\
J^{\text {JAK1 }}{ }^{G O F}, I L 4 R A^{G O F}, T G F B R 1, T G F B R 2, \\
\text { ERBB2IP }\end{array}$ \\
\hline T cell repertoire restriction & $\begin{array}{l}\text { RAG1, RAG2, DCLRE1C, ADA, IL2RG, } \\
\text { IL7RA, CHD7, LIG4, ZAP70, 22q11del }\end{array}$ \\
\hline Tolerance failure & $\begin{array}{l}\text { FOXP3, IL2RA, STAT5B LOF, TGFBR1, TGF } \\
\text { BR2, WAS, CARD } 11, \text { STAT1 }{ }^{G O F}\end{array}$ \\
\hline Metabolic disturbance & PGM3, CARD11, MALT1 \\
\hline Skin barrier disruption & FLG, CDSN, DSG1, DSP, SPINK5 \\
\hline Mast cell deregulation & KIT, PLCG2, ADGRE2, TPSAB1 \\
\hline
\end{tabular}

WIP not only stabilizes WASP but links it to dedicator of cytokinesis 8 (DOCK8), a guanine nucleotide exchange factor (GEF) that activates small $\mathrm{G}$ proteins. The GEF activity of DOCK8 has been shown to be essential to the function of WASP after T cell activation (Janssen et al., 2016). Initially described in 2009 as the first cause for an autosomal recessive syndrome associated with significant elevations in IgE, loss-of-function mutations in DOCK8 lead to a progressive combined immunodeficiency with many clinical features in common with WAS, including severe atopic dermatitis and food allergy (Zhang et al., 2009). Although DOCK8 and WASP are similarly expressed in many humans cell lineages, functional defects identified in WASP-deficient mast cells (Pivniouk et al., 2003), and an ostensibly redundant role for DOCK8 in mast cells (Ogawa et al., 2014), may help explain why clinical manifestations of allergic disease and reactions are less severe in WAS (Pivniouk et al., 2003; Lexmond et al., 2016). DOCK8 deficiency is further distinguished from WAS by a number of different clinical phenotypes, including, but not limited to, a lack of thrombocytopenia and a significantly increased susceptibility to viral infections.

Why Th2 phenotypes emerge from these actin cytoskeletonrelated mutations is not entirely clear. Mutations in WAS and DOCK8 both impair cellular migration and survival, and WAS mutant B cells and dendritic cells display altered phenotypes, all of which may contribute to atopy (Thrasher and Burns, 2010; Zhang et al., 2014a). However, recent data in DOCK8 patient lymphocytes suggest a T cell-intrinsic mechanism whereby DOCK8 deficiency preferentially skews $\mathrm{CD}^{+}$cells toward a Th2 and away from a Th1 bias (Tangye et al., 2017). Consistent with the concomitant autoimmunity seen in these disorders, evidence for regulatory $\mathrm{T}$ ( $\mathrm{T}$ reg) cell dysfunction has also been observed (as discussed later in the section on tolerance failure; HumbletBaron et al., 2007; Maillard et al., 2007; Marangoni et al., 2007; Lexmond et al., 2016; Alroqi et al., 2017).

In addition to TCR engagement by $\mathrm{pMHC}$, costimulation or a second signal has been shown to be critical for $\mathrm{T}$ cell activation. This is provided by engagement of CD28 on the T cell surface by the ligand B-7 expressed on activated antigen-presenting cells, and impairment in costimulation could conceivably promote
Th2 skewing. Recently, autosomal recessive loss-of-function mutations in capping protein regulator and myosin 1 linker 2 (CARMIL2) encoding RGD, leucine-rich repeat, tropomodulin, and proline-rich-containing protein (RLTPR), a protein shown to be critical for CD28 signaling in human T cells (Roncagalli et al., 2016), was shown to cause a combined immunodeficiency (Wang et al., 2016). In addition to susceptibility to infection, these patients present with severe atopic dermatitis, significantly elevated IgE, allergic asthma, food allergy, and cold urticaria; reduced $\mathrm{T}$ reg number was also observed in these patients and may contribute to these atopic phenotypes.

\section{T cell repertoire restriction}

Lymphocytes exhibiting weak TCR activation may also be permitted to expand inappropriately when abnormalities in the TCR repertoire are present. TCR diversity is extremely broad, with estimates of $2.5 \times 10^{7}$ unique antigen receptors present in any given healthy individual (Arstila et al., 1999). A robust TCR repertoire promotes nondeleterious adaptive immune responses by ensuring that $\mathrm{T}$ regulatory and effector specificities overlap and by dictating the strength of prevailing effector TCR-pMHC complex signals through selective and/or competitive mechanisms. In human disease, atopy is among the potential consequences of alterations in this repertoire.

Children with congenital HIV infection have been shown to have restricted TCR diversity, and an increased prevalence of allergic disease, principally in the form of atopic dermatitis, has been reported among these patients relative to HIV-exposed, uninfected infants (Siberry et al., 2012). Although HIV infection and antiretroviral therapy may have other effects on the immune system, more significant repertoire deficits resulting from hypomorphic mutations in genes associated with SCID (see this section in Table 1 for a list of reported genes) have been associated with Th2 inflammation. In these patients, gene function is sufficient to allow, in only a subset of carriers, a small number of $\mathrm{T}$ cells to develop and oligoclonally expand (Shearer et al., 2014; Yu et al., 2014). This "leaky" phenotype presents in infancy as Omenn syndrome with marked Th2 skewing and inflammation, characterized by severe eczema and erythroderma, elevated IgE, and peripheral eosinophilia. Omenn syndrome does not represent classical allergy, as it is unlikely there is allergen-specificity among the effector cells (Villa et al., 2008), and skin lesions tend to be more severe and earlier in onset than classical atopic dermatitis lesions. However, these lesions share many pathological features with atopic dermatitis, and clinically can be indistinguishable with a number of inherited infantile erythrodermas which are associated with classical allergy (discussed later in the skin barrier disruption section). A large number of SCID-associated genes, as well as atypical complete DiGeorge syndrome, have now been reported to present with this severely Th2-skewed phenotype (Markert et al., 2004; Villa et al., 2008; Turul et al., 2009; Joshi et al., 2012). Combined immunodeficiencies caused by recessive mutations in PGM3,WAS, and DOCK8 also present with $\mathrm{T}$ lymphopenia, significant elevations in IgE, and severe clinical allergic disease; combined immunodeficiency caused by STK4 mutations presents similarly, but with more modest IgE elevations and allergic disease (Wada et al., 2005; Dasouki et al., 
2011; Crequer et al., 2012; Sassi et al., 2014; Zhang et al., 2014b; Ben-Khemis et al., 2017). Individuals with these syndromes likely have impaired TCR repertoires, but precise alterations in T cell diversity have not been extensively examined.

Mechanistically, repertoire disturbances have been postulated to lead to atopic phenotypes via two putative mechanisms: (1) reduced TCR diversity creates gaps in regulatory T cell repertoires that cannot appropriately limit effector $\mathrm{T}$ cell responses, as demonstrated in mouse models (Milner et al., 2007; Haribhai et al., 2011) and in atopic patients with ADA deficiency or idiopathic CD4 lymphopenia (Lawrence et al., 2013); (2) the absence of higher affinity antigen-specific TCR-expressing cells during naive $\mathrm{T}$ cell priming results in a noncompetitive expansion of lower-affinity $\mathrm{CD} 4^{+}$clones and subsequent differentiation into Th2 effectors (Milner et al., 2010). Among genes associated with Omenn syndrome, hypomorphic mutations in genes such as $R A G$ have been associated with autoimmunity in the absence of allergy, whereas hypomorphic mutations in other genes, such as CARD11, have been associated with allergy in the absence of autoimmunity. This disparity suggests additional genetic and environmental factors are also likely required for development of these disparate clinical phenotypes.

\section{Altered cytokine signaling}

The monogenic disorder that historically has been most closely associated with atopy is the autosomal dominant hyper-IgE syndrome caused by dominant negative mutations in signal transducer and activator of transcription 3 (STAT3 ${ }^{D N}$ ) (Holland et al., 2007; Minegishi et al., 2007). Patients present with marked IgE elevation and eczematous dermatitis, but also a wide variety of mucosal infections and other protean manifestations. Studies characterizing the allergic manifestations in this syndrome have shown that patients actually have less IgE-mediated immediate hypersensitivity than might have been expected (Siegel et al., 2013; Boos et al., 2014). However, the prevalence of peripheral eosinophilia and eosinophilic gastrointestinal disease (EGID), a food antigen-dependent atopic condition, is significantly increased (Arora et al., 2017). These findings have highlighted important roles for STAT3 in normal mast cell reactivity and vascular permeability (Siegel et al., 2013; Erlich et al., 2014; Hox et al., 2016), with $S T A T 3^{D N}$ mutations generally limiting the severity of allergic reactions, despite the presence of antigen-specific IgE in serum of patients with STAT3 ${ }^{D N}$ mutations, increased levels of Th2 effector cells, and elevated surface IL4R $\alpha$ expression on STAT3 ${ }^{D N}$ lymphocytes (Deenick et al., 2013; Ma et al., 2015; Lyons et al., 2017).

Some of the protean manifestations observed in STAT3 ${ }^{D N}$ individuals include connective tissue phenotypes such as scoliosis, retained primary dentition, aneurysm formation, and joint hypermobility (Holland et al., 2007). These are strikingly similar findings to those seen among patients with diseases of altered TGF- $\beta$ signaling (Lindsay and Dietz, 2014). Moreover, a strong signature for TGF- $\beta$ pathway activation and cytokine expression has been demonstrated in a number of allergic diseases, including severe asthma and EGID (Balzar et al., 2005; Rawson et al., 2016), and a number of connective tissue phenotypes associated with increased SMAD signaling in tissues have been reported among atopic patients (Morgan et al., 2007; Abonia et al., 2013). Heterozygous mutations in transforming growth factor $\beta$ receptor 1 and 2 (TGFBR1 and TGFBR2) lead to the Loeys-Dietz Syndrome (LDS), in which patients suffer a number of vascular and connective tissue abnormalities (Loeys et al., 2006) and also have a significantly increased prevalence of IgE-mediated food allergies, EGID, allergic asthma, and atopic dermatitis (FrischmeyerGuerrerio et al., 2013). These mutations are associated with enhanced SMAD2/3 phosphorylation in primary cells ex vivo, which may contribute to the pathogenesis of allergic diseases. Similar connective tissue phenotypes have been reported in individuals with lesions in a number of molecules in this pathway, including FBN and TNXB mutations, which result in excess free TGF- $\beta$ seen in Marfan and Ehlers-Danlos syndromes (Dietz et al., 1991; Schalkwijk et al., 2001), respectively, as well as in SMAD3, TGFB2, TGFB3, and SKI (Lindsay and Dietz, 2014). Allergic disease prevalence in these individuals has not yet been systematically evaluated.

Recently a family with a heterozygous loss-of-function mutation in erbb2-interacting protein (ERBB2IP), encoding the negative TGF- $\beta$ regulator ERBIN was identified with an intermediate phenotype between $S T A T 3^{D N}$ and LDS patients, providing a putative link between these two disorders (Lyons et al., 2017). STAT3 appears to induce and complex with ERBIN to limit SMAD2/3 nuclear localization, thereby limiting pathway activation. Loss of STAT3 signaling or ERBIN expression in lymphocytes both led to enhanced TGF- $\beta$ pathway activation and increased IL4R $\alpha$ expression, which has been shown to be up-regulated in other cell types by TGF- $\beta$ (Chen et al., 2015). In addition to the well-defined roles for IL4R $\alpha$ in Th2 differentiation and IgE production, a relatively common gain-of-function IL4RA variant has been shown to impart risk for allergy (Hershey et al., 1997), and chronic pruritis has been shown to have a critical dependence on IL4Ra signaling via janus associated kinase 1 (JAK1) activation in neurons (Oetjen et al., 2017).

Patients with gain-of-function mutations in STAT3 (STAT3 ${ }^{G O F}$ ) present with a phenotype in stark contrast to those with $S T A T 3^{D N}$, including early onset autoimmunity, lymphoproliferation, and other immune defects (Milner et al., 2015). However, eczematous dermatitis can be seen in a substantial proportion of these patients as well. Cross-regulation of STAT5 by STAT3 has been demonstrated (Yang et al., 2011; Olson et al., 2016), and patients with STAT3 ${ }^{G O F}$ have diminished STAT5 responses, likely explaining some of the shared clinical phenotypes with STAT5B loss-of-function (STAT5B ${ }^{L O F}$ ) patients who present with short stature, autoimmunity, atopic dermatitis, ichthyosis, and elevated IgE. In both STAT3 ${ }^{G O F}$ and $S T A T 5 B^{L O F}$, we would speculate that atopic phenotypes likely result from regulatory $\mathrm{T}$ cell failure that is discussed in the section on tolerance failure (Nadeau et al., 2011; Kanai et al., 2012). It is therefore noteworthy that excessive STAT5 signaling has also been shown to result in atopic and myeloproliferative phenotypes in mouse models (Ando et al., 2014; Kawakami et al., 2015) and that a somatic heterozygous gain-of-function STAT5B (STAT5B ${ }^{G O F}$ ) mutation that had previously been reported in association with leukemia and lymphoma (Rajala et al., 2013; Bandapalli et al., 2014; Küçük et al., 2015) was recently observed in two unrelated children who 
presented without neoplastic disease, but rather dermatitis, diarrhea, marked eosinophilia, and urticaria beginning very early in life (Ma et al., 2017b).

Further evidence for a role of altered JAK-STAT signaling in allergic disease can be found in a family with a gain-of-function mutation in JAK1 (JAK1 ${ }^{G O F}$ ) which can facilitate STAT5B phosphorylation (Del Bel et al., 2017). Affected family members had severe atopic dermatitis, marked peripheral and tissue eosinophilia on a scale similar to that seen in the somatic STAT5B ${ }^{G O F}$ patients, and allergic asthma. This JAK1 ${ }^{G O F}$ mutation was in the inhibitory domain leading to hyperactivity after cytokine stimulation. Of critical importance, these patients demonstrated marked clinical improvement with ruxolitinib, a JAK inhibitor used to treat proliferative and inflammatory diseases; minimal adverse consequences have been observed thus far in the JAK ${ }^{G O F}$ individuals. These findings highlight the power of detecting monogenic causes for allergic diseases, as a pathway-specific therapy could be implemented with marked improvement in clinical disease.

Recessive TYK2 mutations, which function similarly to JAKs, were initially described in a single patient with elevated IgE and susceptibility to mycobacterial infection (Minegishi et al., 2006). However subsequent patients identified with TYK2 deficiency have not had evidence of atopy or high IgE, and subsequent study of the sentinel patient's mutation has indicated that TYK2 mutations may not have been responsible for the allergic phenotype, given that IL- 6 responses, impaired in the patient, are normal in all other identified individuals with recessive TYK2 mutations, including complete loss of function (Kreins et al., 2015).

\section{Tolerance failure}

Another fundamental mechanism that can promote allergic diseases in humans was first suggested by a spontaneous mutation that resulted in the "scurfy" mouse line nearly $70 \mathrm{yr}$ ago. Characterized by xerotic skin, conjunctival injection, and spontaneous autoimmunity, the genetic cause for this phenotype was successfully identified as an X-linked recessive mutation in forkhead box P3 (Foxp3) in 2001 (Brunkow et al., 2001). In humans, X-linked recessive mutations in FOXP3 cause immunodysregulation polyendocrinopathy enteropathy X-linked (IPEX) syndrome (Chatila et al., 2000; Bennett et al., 2001; Wildin et al., 2001). In addition to autoimmune disease, affected individuals present with severe atopic dermatitis, high IgE, and eosinophilia. These patients lack $T$ regs which require FOXP3 for lineage stability and suppressive activity (Ramsdell and Ziegler, 2014). In IPEX, both central and peripheral $\mathrm{T}$ regs are absent, the latter of which are believed to normally limit allergic disease. Indeed, mice deficient in the conserved noncoding sequence 1 (CNS1), which has been shown to be critical for peripheral $\mathrm{T}$ reg identity, develop spontaneous eosinophilia and allergic inflammation of the gut and lung (Josefowicz et al., 2012).

Additional lesions in pathways critical to $\mathrm{T}$ reg cell development, maintenance, and/or function have been described to result in IPEX-like phenotypes, including null mutations in the IL-2 coreceptor CD25 (Caudy et al., 2007), encoded by IL2RA, and the loss-of-function mutations in STAT5B described.

IL-2 signaling via STAT5 has been shown to be a critical positive regulator of the suppressive cytokine IL-10. IL-10 expression appears to be defective in patients with IL2RA loss-of-function mutations and is likely disrupted in patients with STATSB ${ }^{L O F}$ mutations as well. Because a dominant pathway of IL-10 signaling occurs via STAT3, STAT3 signaling is markedly reduced by $S T A T 3^{D N}$ mutations, and because IL-10 is an immunomodulatory or even suppressive cytokine in the context of allergen immunotherapy and high-dose allergen exposure (Akdis and Blaser, 2001; Vissers et al., 2004; Meiler et al., 2008), it is tempting to invoke this pathway as a major regulator of atopic disease generally. However, whereas damaging mutations in IL10, IL1ORA, and IL1ORB all lead to profound early onset inflammatory bowel disease (Glocker et al., 2009, 2010; Kotlarz et al., 2012), allergic inflammation has not been reported in these patients. It remains possible that overwhelming Th1-associated inflammation suppresses allergic sensitization and allergy in these individuals. However, the importance of IL-10 signaling in peripheral T reg-mediated suppression of allergic inflammation in vivo, as has been demonstrated for Trl-mediated tolerance in nonatopic individuals, remains to be demonstrated in humans.

A number of other primary atopic disorders also have evidence of $\mathrm{T}$ reg dysfunction implicated in the pathogenesis of observed allergic phenotypes. Human WASP-deficient $T$ regs have impaired fitness and suppressive function (HumbletBaron et al., 2007; Maillard et al., 2007; Marangoni et al., 2007), and in a mouse model of Wiskott-Aldrich syndrome, spontaneous food allergy is exacerbated by selective deletion of WASp in $\mathrm{T}$ regs (Lexmond et al., 2016). Rltpr encoded by Carmil2 which is downstream of CD28 and participates in actin polymerization, has likewise been demonstrated as indispensable for $\mathrm{T}$ reg development in mice (Liang et al., 2013), and humans with CARMIL2 deficiency have been shown to have a significant reduction of $\mathrm{T}$ regs in circulation (Wang et al., 2016; Schober et al., 2017). DOCK8-deficient and STAT1 ${ }^{G O F}$ patients can also present with IPEX-like phenotypes: the former appears to cause $\mathrm{T}$ reg dysfunction principally by limiting IL-2-mediated STAT5 activation, whereas direct effects of $S T A T 1^{G O F}$ mutations on $\mathrm{T}$ regs have not been established (Uzel et al., 2013; Janssen et al., 2014, 2017; Alroqi et al., 2017; Singh et al., 2017). Finally, $\mathrm{T}$ reg disruption has also been demonstrated in LDS patients, as might be expected in a disease associated with abnormal TGF- $\beta$ pathway signaling. Enhanced SMAD activation that has been reported in vivo in these patients (Loeys et al., 2006), is associated with an increased frequency of $\mathrm{FOXP} 3^{+} \mathrm{CD} 4^{+} \mathrm{T}$ cells (Frischmeyer-Guerrerio et al., 2013); however, these cells have been shown to produce Th2-associated cytokines both ex vivo and in vitro (Frischmeyer-Guerrerio et al., 2013). Aberrant Th2-effector cytokine expression has been similarly shown to occur in $\mathrm{FOXP}^{+}{ }^{+} \mathrm{CD} 4^{+}$antigen-specific $\mathrm{T}$ cells from food-allergic patients after in vitro expansion (Noval Rivas et al., 2015), suggesting impaired $\mathrm{T}$ reg lineage commitment may be a common defect that can promote a break in peripheral tolerance.

\section{Metabolic disturbance}

The first evidence that germline alterations in hexosamine biosynthesis can lead to severe clinical allergy in humans was provided by the identification of autosomal recessive mutations in phosphoglucomutase 3 (PGM3). PGM3 deficiency is associated 
with a remarkable number and intensity of allergic diseases including severe atopic dermatitis, food allergy, immediate and delayed hypersensitivity to medications, EGID, asthma, seasonal allergy, allergic bronchopulmonary aspergillosis, allergic fungal mastoiditis, and food-protein induced enteropathy syndrome (Sassi et al., 2014; Stray-Pedersen et al., 2014; Zhang et al., 2014b; Bernth-Jensen et al., 2016; Ben-Khemis et al., 2017). Hypomorphic mutations in PGM3 result in impaired formation of uridine diphosphate $\mathrm{N}$-acetylglucosamine (UDP-GlcNAc; Zhang et al., 2014b; Carlson et al., 2017). This monosaccharide donor that is essential for normal glycosylation is significantly reduced in PGM3 deficient cells, leading to altered glycosylation. Lineage specificity of glycosylation changes are observed in $\mathrm{T}$ cells (Zhang et al., 2014b; Carlson et al., 2017) and may reflect differences in cellular metabolism of varying lymphocyte subsets. Additional evidence suggests this phenomenon also occurs in other cell types, as hepatocyte-derived serum transferrin displays abnormal N-glycosylation, whereas plasma cell-derived IgE, despite being markedly elevated, appears to be normally glycosylated (Wu et al., 2016). How altered nucleotide-sugar pools or glycoproteins may promote the severe allergic phenotypes observed remains to be deciphered.

Metabolic disruption may also play a role in the atopic phenotypes observed in individuals with heterozygous CARD11 or MALT1 mutations. Although the CBM complex is critical for mediating TCR signals, it also has a role in regulating the flux of glutamine, a critical amino acid required for GlcNAc formation, $\mathrm{mTORC} 1$ activation, and cellular metabolism. After $\mathrm{T}$ cell activation, the CBM complex is required for recruitment of alanine-serine-cysteine-preferring transporter 2 (ASCT2) to the cell surface in order to sustain glutamine flux, aerobic glycolysis, and clonal expansion (Nakaya et al., 2014). Loss of ASCT2 expression or glutamine deprivation prevents $\mathrm{mTORC1}$ activation, proliferation, and Th1/17 cytokine production in mouse $\mathrm{T}$ cells, and heterozygous loss-of-function CARD11 mutations in humans have been shown to likewise result in impaired phosphorylation of S6, reduced Thl cytokine production, and increased clinical allergic disease (Ma et al., 2017a). These data suggest that a selective bias away from mTORC1 utilization may promote allergic phenotypes in humans, as has been demonstrated in mouse models (Delgoffe et al., 2011). A previous genome-wide association study independently identified CARD11 as a major susceptibility locus for atopic dermatitis (Hirota et al., 2012), and a trial providing glutamine-enriched formula to premature infants demonstrated a protective effect on incident atopic dermatitis (van den Berg et al., 2007), suggesting glutamine supplementation could be of clinical value in select individuals with atopic dermatitis.

\section{Skin barrier disruption}

Th2 inflammation can disrupt skin barrier integrity leading to atopic dermatitis, which in many patients is the heralding clinical sign of atopy. A mechanism by which this occurs is via suppression of filaggrin (FLG) expression in keratinocytes by the Th2-associated cytokines IL-4, IL-13, and IL-25 (Howell et al., 2007; Hvid et al., 2011). FLG is derived from posttranslational cleavage of an extremely large ( $>400 \mathrm{kD}$ ) precursor, pro-FLG, which has multiple FLG repeats of varying copy numbers. In the epidermis, pro-FLG undergoes proteolytic processing during normal desquamation and contributes to skin barrier function and hydration, in part through its processing into natural moisturizing factor (NMF; Sandilands et al., 2009).

FLG protein levels have been shown to be selectively reduced in nonlesional skin of patients with atopic dermatitis (Seguchi et al., 1996), suggesting reduced expression of this protein may play a central role in atopy. Homozygous loss-of-function mutations in FLG result in ichthyosis vulgaris (Smith et al., 2006), a condition characterized by extremely dry, pruritic, flaky skin and associated with elevated IgE and allergy. More commonly encountered heterozygous loss-of-function FLG mutations have also been shown to strongly associate with early onset atopic dermatitis, elevated IgE, allergic asthma, and food allergy (Sandilands et al., 2007; Irvine et al., 2011).

To maintain barrier integrity, human skin must withstand shearing forces; this is accomplished by the desmosome, a junctional protein complex which acts as an anchor to resist mechanical stress (Kottke et al., 2006; Jonca et al., 2011). Mutations in genes encoding three desmosomal proteins in human skincorneodesmosin (CDSN), desmoplakin (DSP), and desmoglein-1 (DSGI) - have been found to cause severe atopic dermatitis, elevated IgE, and multiple allergies (Oji et al., 2010; Samuelov et al., 2013; McAleer et al., 2015). Homozygous nonsense and missense mutations in CDSN result in peeling skin syndrome, type B, characterized by diffuse ichthyosis and erythroderma of the skin, which is associated with severe pruritus, elevated IgE, and allergic disease (Oji et al., 2010). A dominant heterozygous mutation in DSP (McAleer et al., 2015) and homozygous recessive mutations in DSG1 (Samuelov et al., 2013) result in the severe dermatitis, multiple allergies and metabolic wasting syndrome. All of these mutations appear to disrupt normal desmosome complex formation or their association with keratin filaments.

The strong intracellular junctions present deep in the skin epithelium must be degraded in a highly regulated manner in order for normal desquamation to occur. Kallikrein family proteases are believed to be the primary enzymes responsible for this, and a major regulator of their activity is lympho-epithelial Kazal-type-related inhibitor (LEKTI) encoded by serine protease inhibitor Kazal-type 5 (SPINK5; Ishida-Yamamoto et al., 2005). Autosomal recessive loss-of-function mutations in SPINK5 lead to deregulated protease activity deep in the epidermis and desmosome destabilization. Affected patients present with the Netherton syndrome, a disorder characterized by excessive desquamation resulting in severe ichthyosis and erythroderma, trichorrhexis invaginatum (bamboo hair), elevated IgE, and atopy (Chavanas et al., 2000).

Retrospective analyses of individuals with ectodermal dysplasias resulting from disruption of the ectodysplasin pathway have also been reported to have a significantly increased prevalence of allergic diseases, including atopic dermatitis, allergic rhinitis, asthma, and food allergy (Mark et al., 2012; Tuano et al., 2015). Although the specific genetic lesions were not included in these clinical studies, the findings would seem to be in line with the reported CBM and skin barrier defects in known primary atopic disorders. However, the mechanisms underlying specific susceptibility and whether impaired NF- $\kappa$ B signaling observed in this 
group of disorders contributes to the immunopathogenesis of atopy requires further examination.

A number of mechanisms have been proposed by which impaired skin barrier function may contribute to allergic pathogenesis. A disrupted skin barrier leads to: (a) unregulated exposure of antigen presenting cells to environmental antigens leading to proinflammatory cytokine expression and epicutaneous sensitization; (b) alterations in the protective skin $\mathrm{pH}$ gradient; (c) perturbations of skin microbiota, including unconstrained growth of Staphylococcus aureus (Jungersted et al., 2010; Miajlovic et al., 2010; Kezic et al., 2012). Interventions to remediate skin barrier function provide the basis for treatments in these patients, but also may hold promise in preventing development of allergic disease. One small prospective trial administering daily emollients to the skin of high-risk infants reduced the cumulative incidence of atopic dermatitis $50 \%$ by 6 mo of age (Simpson et al., 2014).

\section{Mast cell deregulation}

Mast cells are the key effector cells of type I immediate hypersensitivity reactions. Although individuals with mutations that specifically effect this compartment often present with symptoms attributable to type I reactions, these patients are not classically allergic and often display mast cell hyperreactivity to unknown or otherwise innocuous stimuli.

SCF is the primary growth factor for mast cells. Somatic gain-of-function mutations in KIT, the cognate receptor for SCF, in particular the c.2447A $>$ T p.(D816V) missense, allow for SCF-independent signaling and are strongly associated with clonal expansion of mast cells, which can become the acquired atopic disorder called mastocytosis (Valent et al., 2017). Clinically, mastocytosis is characterized by recurrent release of mast cell mediators leading to symptoms of immediate hypersensitivity reactions ranging from flushing, abdominal pain, diarrhea, or wheezing, to severe anaphylaxis, frequently occurring without antigen inducement. Germline gain-of-function mutations in KIT were first described in association with familial gastrointestinal stromal tumors (Nishida et al., 1998). However, it was later discovered that a number of families with both cutaneous and systemic forms of mastocytosis harbor germline gainof-function KIT mutations (Ke et al., 2016).

One of the hallmarks of mast cell mediator release is the formation of characteristic urticarial skin lesions, or hives. Germline mutations in two genes, PLCG2 and adhesion G protein-coupled receptor $E 2$ ( $A D G R E 2)$, have been found to result in urticaria in response to the physical stimuli of cold and vibration, respectively (Ombrello et al., 2012; Boyden et al., 2016).

Cold urticaria is a phenomenon by which exposure to subphysiological temperature induces mast cell activation and urticaria. It is important to distinguish this phenomenon from the cryopyrinopathies, which include the familial cold autoinflammatory syndrome (previously called familial cold urticaria), an autoinflammatory syndrome caused by activating mutations in NLR family pyrin domain containing 3 (NLRP3) that affect the inflammasome and can lead to urticarial skin lesions that are not mast cell-related (Aksentijevich et al., 2007). A distinct familial syndrome associated with mast cell-mediated atypical cold urticaria induced by evaporative cooling is caused by large deletions in the autoinhibitory domains of PLCG2 (Gandhi et al., 2009; Ombrello et al., 2012). At physiological temperature, these lesions lead to impaired signaling of $\mathrm{PLC} \gamma 2$, with impaired B cell receptor-induced calcium flux and diminished ERK1/2 phosphorylation contributing to humoral immune defects in a number of these patients. However, at subphysiological temperatures, spontaneous activation of myeloid-lineage cells expressing PLC $\gamma 2$, including mast cells and granulocytes, is observed. This leads not only to cold-induced urticaria, but can also lead to disfiguring granulomatous inflammation in cooler areas of the skin (such as the tip of the nose and digits; Aderibigbe et al., 2015). The mechanisms underlying temperature sensitivity in mast cells remains unknown, however these mutations provide insight into one pathway that may contribute.

Vibration can be another trigger for mast cell-mediated urticaria. Recently, a mutation in ADGRE2 has been shown to enhance the sensitivity of mast cells to vibration and to lead to a severe familial form of vibratory urticaria (Boyden et al., 2016). EGF-like module-containing mucin-like hormone receptor-like 2 (EMR2) encoded by ADGRE2, is a serpentine adhesion $\mathrm{G}$ protein-coupled receptor (GPCR) which binds to glycosaminoglycans such as dermatan sulfate. Attachment is mediated by a noncovalently bound subunit of the receptor, which when forcefully dissociated permits cellular activation (Huang et al., 2012). The ADGRE2 mutation that promotes enhanced mast cell sensitivity to vibratory stimuli appears to partially disrupt this noncovalent interaction of the receptor subunits and lead to a lower threshold for mechanical dissociation and resultant mast cell degranulation.

The evolutionary purpose for temperature and vibration sensing in mast cells corresponds with their believed purpose of residing in skin and mucosal surfaces where they contribute to both innate and adaptive immune responses (Galli and Tsai, 2010). Lesions in the pathways that contribute to these responses not only provide insights into the mechanisms governing these sensing mechanisms, but also potential new ways to target mast cells and limit physical urticarias or mast cell activation more generally.

Finally, an important allergic mediator present in mast cell secretory granules is the serine protease tryptase. Two major secreted isoforms exist: $\alpha$ - and $\beta$-tryptases. In the mature form, this enzyme is a tetramer stabilized by heparin that is released after degranulation, where it contributes to allergic inflammation, inducing pruritus and contributing to tissue remodeling (Sommerhoff, 2001; Ui et al., 2006). Recently, increased monoallelic copy number of tryptase $\alpha /$ beta 1 (TPSAB1) encoding the $a$-tryptase isoform was identified as the cause of hereditary $a$ tryptasemia, a genetic trait characterized by increased basal serum levels of tryptase (BST) and associated with multisystem complaints, including local and systemic symptoms suggestive of increased mast cell reactivity or mediator release, in three independent cohorts (Lyons et al., 2016). Although the mechanism(s) underlying the association between the reported symptoms and increased or altered tryptase isoform expression is not fully understood, an increase in bone marrow mast cells has been reported in these patients (Lyons et al., 2014). Furthermore, 
a gene dosage effect is observed in affected individuals, where an increasing number of additional TPSAB1 copies is associated with both higher BST and greater expressivity of symptoms. Additional study of tryptase expression and function in these patients may yield important insights into the effects of specific tryptase isoforms on mast cell-mediated reactions and cellular homeostasis. Importantly, the majority of BST elevations, present in 4-6\% of the general population (Gonzalez-Quintela et al., 2010; Fellinger et al., 2014), appears to be attributable to increased TPS $A B 1$ copy number, suggesting that this genetic trait may commonly contribute to some of the clinical phenotypes initially reported, as well as to others clinically associated with elevated BST (Kucharewicz et al., 2007; Fellinger et al., 2014; Sahiner et al., 2014; Doong et al., 2017; Valent et al., 2017).

\section{Final considerations}

Experiments of nature have provided fundamental insights into the immunopathogenesis of allergic diseases in humans. The development of allergy is complex, likely requiring multiple host and environmental factors; through the study of primary atopic disorders and the associated allergic phenotypes caused by discrete monogenic lesions, the hope is to exploit these discoveries to innovate new treatment strategies which can be rationally applied to patients with nonsyndromic allergic diseases. The mechanistic focus of this review has been primarily on $\mathrm{CD}^{+}$ $\mathrm{T}$ lymphocytes and allergic effector cells, given their integral importance in orchestrating and regulating allergic immune responses. However, there are likely additional mechanisms, which are independent of those discussed, that modify and/or directly contribute to the allergic sensitization or reactivity in these genetic diseases, such as B cell-intrinsic defects which may predispose to IgE class switching (Wesemann et al., 2011; Kane et al., 2016; Massaad et al., 2017).

A large number of primary atopic disorders present with elevated, or "hyper-IgE," despite having vastly different underlying etiologies, mechanisms, and treatments. Given the significant potential for confusion of patients and care providers, and the disparate ways these disorders are managed, we strongly favor using more specific terminology that includes the gene name rather than a single clinical feature and inheritance pattern.

With increasing use of clinical exome and genome sequencing, the number of primary atopic disorders will continue to expand. The generous contribution of these patients and their families will no doubt continue to grow and refine our understanding of the mechanisms governing and contributing to allergic diatheses, and ultimately provide the blueprint for personalized therapies in clinical allergic disorders.

\section{Acknowledgments}

The authors thank Ryan Kissinger and Anita Mora from the Visual Medical Arts, Research and Technologies Branch, National Institute of Allergy and Infectious Diseases for their graphical contribution.

This work was supported by the Division of Intramural Research of the National Institute of Allergy and Infectious Diseases, National Institutes of Health.
The authors declare no competing financial interests.

Submitted: 18 December 2017

Revised: 21 February 2018

Accepted: 1 March 2018

\section{References}

Abonia, J.P., T. Wen, E.M. Stucke, T. Grotjan, M.S. Griffith, K.A. Kemme, M.H Collins, P.E. Putnam, J.P. Franciosi, K.F. von Tiehl, et al. 2013. High prevalence of eosinophilic esophagitis in patients with inherited connective tissue disorders. J. Allergy Clin. Immunol. 132:378-386. https://doi.org/10 .1016/j.jaci.2013.02.030

Aderibigbe, O.M., D.L. Priel, C.C. Lee, M.J. Ombrello, V.H. Prajapati, M.G. Liang, J.J. Lyons, D.B. Kuhns, E.W. Cowen, and J.D. Milner. 2015. Distinct Cutaneous Manifestations and Cold-Induced Leukocyte Activation Associated With PLCG2 Mutations. JAMA Dermatol. 151:627-634. https://doi.org/10 .1001/jamadermatol.2014.5641

Akdis, C.A., and K. Blaser. 2001. Role of IL-10 in allergen-specific immunotherapy and normal response to allergens. Microbes Infect. 3:891-898. https://doi.org/10.1016/S1286-4579(01)01449-6

Aksentijevich, I., C.D. Putnam, E.F. Remmers, J.L. Mueller, J. Le, R.D. Kolodner, Z. Moak, M. Chuang, F. Austin, R. Goldbach-Mansky, et al. 2007. The clinical continuum of cryopyrinopathies: novel CIAS1 mutations in North American patients and a new cryopyrin model. Arthritis Rheum. 56:1273-1285. https://doi.org/10.1002/art.22491

Alroqi, F.J., L.M. Charbonnier, S. Keles, F. Ghandour, P. Mouawad, R. Sabouneh, R. Mohammed, A. Almutairi, J. Chou, M.J. Massaad, et al. 2017. DOCK8 Deficiency Presenting as an IPEX-Like Disorder.J. Clin. Immunol. 37:811-819. https://doi.org/10.1007/s10875-017-0451-1

Ando, T., W. Xiao, P. Gao, S. Namiranian, K. Matsumoto, Y. Tomimori, H. Hong, H. Yamashita, M. Kimura, J. Kashiwakura, et al. 2014. Critical role for mast cell Stat5 activity in skin inflammation. Cell Reports. 6:366-376. https://doi.org/10.1016/j.celrep.2013.12.029

Arora, M., P. Bagi, A. Strongin, J. Heimall, X. Zhao, M.G. Lawrence, A. Trivedi, C. Henderson, A. Hsu, M. Quezado, et al. 2017. Gastrointestinal Manifestations of STAT3-Deficient Hyper-IgE Syndrome. J. Clin. Immunol. 37:695-700. https://doi.org/10.1007/s10875-017-0429-z

Arpaia, E., M. Shahar, H. Dadi, A. Cohen, and C.M. Roifman. 1994. Defective $\mathrm{T}$ cell receptor signaling and $\mathrm{CD} 8+$ thymic selection in humans lacking zap-70 kinase. Cell. 76:947-958. https://doi.org/10.1016/0092 -8674(94)90368-9

Arstila, T.P., A. Casrouge, V. Baron, J. Even, J. Kanellopoulos, and P. Kourilsky. 1999. A direct estimate of the human alphabeta T cell receptor diversity. Science. 286:958-961. https://doi.org/10.1126/science.286.5441.958

Bacchelli, C., F.A. Moretti, M. Carmo, S. Adams, H.C. Stanescu, K. Pearce, M. Madkaikar, K.C. Gilmour, A.K. Nicholas, C.G. Woods, et al. 2017. Mutations in linker for activation of T cells (LAT) lead to a novel form of severe combined immunodeficiency. J. Allergy Clin. Immunol. 139:634642.e5. https://doi.org/10.1016/j.jaci.2016.05.036

Balzar, S., H.W. Chu, P. Silkoff, M. Cundall, J.B. Trudeau, M. Strand, and S. Wenzel. 2005. Increased TGF-beta2 in severe asthma with eosinophilia. J. Allergy Clin. Immunol. 115:110-117. https://doi.org/10.1016/j.jaci.2004 .09 .034

Bandapalli, O.R., S. Schuessele, J.B. Kunz, T. Rausch, A.M. Stütz, N. Tal, I. Geron, N. Gershman, S. Izraeli, J. Eilers, et al. 2014. The activating STAT5B N642H mutation is a common abnormality in pediatric T-cell acute lymphoblastic leukemia and confers a higher risk of relapse. Haematologica. 99:e188-e192. https://doi.org/10.3324/haematol.2014 104992

Barber, J.S., L.K. Yokomizo, V. Sheikh, A.F. Freeman, E. Garabedian, E. van Dijk, R. Sokolic, F. Candotti, N.P. Weng, I. Sereti, and J.D. Milner. 2013. Peptide library-based evaluation of T-cell receptor breadth detects defects in global and regulatory activation in human immunologic diseases. Proc. Natl. Acad. Sci. USA. 110:8164-8169. https://doi.org/10.1073/ pnas. 1302103110

Ben-Khemis, L., N. Mekki, I. Ben-Mustapha, K. Rouault, F. Mellouli, M. Khemiri, M. Bejaoui, L. Essaddam, S. Ben-Becher, L. Boughamoura, et al. 2017. A founder mutation underlies a severe form of phosphoglutamase 3 (PGM3) deficiency in Tunisian patients. Mol. Immunol. 90:57-63. https://doi.org/10.1016/j.molimm.2017.06.248

Bennett, C.L., J. Christie, F. Ramsdell, M.E. Brunkow, P.J. Ferguson, L. Whitesell, T.E. Kelly, F.T. Saulsbury, P.F. Chance, and H.D. Ochs. 2001. The 
immune dysregulation, polyendocrinopathy, enteropathy, X-linked syndrome (IPEX) is caused by mutations of FOXP3. Nat. Genet. 27:20-21. https://doi.org/10.1038/83713

Bernth-Jensen, J.M., M. Holm, and M. Christiansen. 2016. Neonatal-onset T(-) $\mathrm{B}(-) \mathrm{NK}(+)$ severe combined immunodeficiency and neutropenia caused by mutated phosphoglucomutase 3.J. Allergy Clin. Immunol. 137:321-324. https://doi.org/10.1016/j.jaci.2015.07.047

Bertin, J., L. Wang, Y. Guo, M.D. Jacobson, J.L. Poyet, S.M. Srinivasula, S. Merriam, P.S. DiStefano, and E.S. Alnemri. 2001. CARD11 and CARD14 are novel caspase recruitment domain (CARD)/membrane-associated guanylate kinase (MAGUK) family members that interact with BCL10 and activate NF-kappa B. J. Biol. Chem. 276:11877-11882. https://doi.org/10 $.1074 /$ jbc.M010512200

Boos, A.C., B. Hagl, A. Schlesinger, B.E. Halm, N. Ballenberger, M. Pinarci, V. Heinz, D. Kreilinger, B.D. Spielberger, L.F. Schimke-Marques, et al. 2014. Atopic dermatitis, STAT3- and DOCK8-hyper-IgE syndromes differ in IgE-based sensitization pattern. Allergy. 69:943-953. https://doi.org/10 $.1111 /$ all.12416

Boyden, S.E., A. Desai, G. Cruse, M.L. Young, H.C. Bolan, L.M. Scott, A.R. Eisch, R.D. Long, C.C. Lee, C.L. Satorius, et al. 2016. Vibratory Urticaria Associated with a Missense Variant in ADGRE2. N. Engl. J. Med. 374:656-663. https://doi.org/10.1056/NEJMoal500611

Brunkow, M.E., E.W. Jeffery, K.A. Hjerrild, B. Paeper, L.B. Clark, S.A. Yasayko, J.E. Wilkinson, D. Galas, S.F. Ziegler, and F. Ramsdell. 2001. Disruption of a new forkhead/winged-helix protein, scurfin, results in the fatal lymphoproliferative disorder of the scurfy mouse. Nat. Genet. 27:68-73. https://doi.org/10.1038/83784

Carlson, R.J., M.R. Bond, S. Hutchins, Y. Brown, L.A. Wolfe, C. Lam, C. Nelson, T. DiMaggio, N. Jones, S.D. Rosenzweig, et al. 2017. Detection of phosphoglucomutase-3 deficiency by lectin-based flow cytometry. J. Allergy Clin. Immunol. 140:291-294.e4. https://doi.org/10.1016/j.jaci.2016.12.951

Caudy, A.A., S.T. Reddy, T. Chatila, J.P. Atkinson, and J.W. Verbsky. 2007. CD25 deficiency causes an immune dysregulation, polyendocrinopathy, enteropathy, X-linked-like syndrome, and defective IL-10 expression from CD4 lymphocytes. J. Allergy Clin. Immunol. 119:482-487. https://doi .org/10.1016/j.jaci.2006.10.007

Chan, A.C., T.A. Kadlecek, M.E. Elder, A.H. Filipovich, W.L. Kuo, M. Iwashima, T.G. Parslow, and A. Weiss. 1994. ZAP-70 deficiency in an autosomal recessive form of severe combined immunodeficiency. Science. 264:1599-1601. https://doi.org/10.1126/science.8202713

Chatila, T.A., F. Blaeser, N. Ho, H.M. Lederman, C. Voulgaropoulos, C. Helms, and A.M. Bowcock. 2000. JM2, encoding a fork head-related protein, is mutated in X-linked autoimmunity-allergic disregulation syndrome. J. Clin. Invest. 106:R75-R81. https://doi.org/10.1172/JCI11679

Chavanas, S., C. Bodemer, A. Rochat, D. Hamel-Teillac, M. Ali, A.D. Irvine, J.L. Bonafé, J. Wilkinson, A. Taïeb, Y. Barrandon, et al. 2000. Mutations in SPINK5, encoding a serine protease inhibitor, cause Netherton syndrome. Nat. Genet. 25:141-142. https://doi.org/10.1038/75977

Chen, C., K. Akiyama, D. Wang, X. Xu, B. Li, A. Moshaverinia, F. Brombacher, L. Sun, and S. Shi. 2015. mTOR inhibition rescues osteopenia in mice with systemic sclerosis. J. Exp. Med. 212:73-91. https://doi.org/10.1084/ jem.20140643

Coca, A. F., R.A. Cooke 1923. On the Classification of the Phenomena of Hypersensitiveness. J. Immunol. 8:163-182.

Constant, S.L., and K. Bottomly. 1997. Induction of Th1 and Th2 CD4+ T cell responses: the alternative approaches. Annu. Rev. Immunol. 15:297-322. https://doi.org/10.1146/annurev.immunol.15.1.297

Cooke, R.A. 1947. Allergy in Theory and Practice. W.B. Saunders Company, Philadelphia.

Crequer, A., C. Picard, E. Patin, A. D’Amico, A. Abhyankar, M. Munzer, M. Debré, S.Y. Zhang, G. de Saint-Basile, A. Fischer, et al. 2012. Inherited MST1 deficiency underlies susceptibility to EV-HPV infections. PLoS One. 7:e44010. https://doi.org/10.1371/journal.pone.0044010

Dadi, H., Jones, T. A., Merico, D., Sharfe, N., Ovadia, A., Schejter, Y., Reid, B., Sun, M., Vong, L., Atkinson, A., Lavi, S., Pomerantz, J. L. \& Roifman, C. M.2017. Combined immunodeficiency and atopy caused by a dominant negative mutation in caspase activation and recruitment domain family member 11 (CARD11). J. Allergy Clin. Immunol.

Dasouki, M., K.C. Okonkwo, A. Ray, C.K. Folmsbeel, D. Gozales, S. Keles, J.M. Puck, and T. Chatila. 2011. Deficient T Cell Receptor Excision Circles (TRECs) in autosomal recessive hyper IgE syndrome caused by DOCK8 mutation: implications for pathogenesis and potential detection by newborn screening. Clin. Immunol. 141:128-132. https://doi.org/10.1016/ j.clim.2011.06.003
Deenick, E.K., D.T. Avery, A. Chan, L.J. Berglund, M.L. Ives, L. Moens, J.L. Stoddard, J. Bustamante, S. Boisson-Dupuis, M. Tsumura, et al. 2013. Naive and memory human B cells have distinct requirements for STAT3 activation to differentiate into antibody-secreting plasma cells. J. Exp. Med. 210:2739-2753. https://doi.org/10.1084/jem.20130323

Del Bel, K.L., R.J. Ragotte, A. Saferali, S. Lee, S.M. Vercauteren, S.A. Mostafavi, R.A. Schreiber, J.S. Prendiville, M.S. Phang, J. Halparin, et al. 2017. JAK1 gain-of-function causes an autosomal dominant immune dysregulatory and hypereosinophilic syndrome. J. Allergy Clin. Immunol. 139:20162020.e5. https://doi.org/10.1016/j.jaci.2016.12.957

Delgoffe, G.M., K.N. Pollizzi, A.T. Waickman, E. Heikamp, D.J. Meyers, M.R. Horton, B. Xiao, P.F. Worley, and J.D. Powell. 2011. The kinase mTOR regulates the differentiation of helper $\mathrm{T}$ cells through the selective activation of signaling by mTORC1 and mTORC2. Nat. Immunol. 12:295-303. https://doi.org/10.1038/ni.2005

Dietz, H.C., G.R. Cutting, R.E. Pyeritz, C.L. Maslen, L.Y. Sakai, G.M. Corson, E.G. Puffenberger, A. Hamosh, E.J. Nanthakumar, S.M. Curristin, et al. 1991. Marfan syndrome caused by a recurrent de novo missense mutation in the fibrillin gene. Nature. 352:337-339. https://doi.org/10.1038/ $352337 \mathrm{a} 0$

Doong, J.C., K. Chichester, E.T. Oliver, L.B. Schwartz, and S.S. Saini. 2017. Chronic Idiopathic Urticaria: Systemic Complaints and Their Relationship with Disease and Immune Measures. J. Allergy Clin. Immunol. Pract. 5:1314-1318. https://doi.org/10.1016/j.jaip.2016.11.037

Elder, M.E., D. Lin, J. Clever, A.C. Chan, T.J. Hope, A. Weiss, and T.G. Parslow. 1994. Human severe combined immunodeficiency due to a defect in ZAP-70, a T cell tyrosine kinase. Science. 264:1596-1599. https://doi.org/ $10.1126 /$ science. 8202712

Erlich, T.H., Z. Yagil, G. Kay, A. Peretz, H. Migalovich-Sheikhet, S. Tshori, H. Nechushtan, F. Levi-Schaffer, A. Saada, and E. Razin. 2014. Mitochondrial STAT3 plays a major role in IgE-antigen-mediated mast cell exocytosis. J. Allergy Clin. Immunol. 134:460-469.e10. https://doi.org/10.1016/ j.jaci.2013.12.1075

Fellinger, C., W. Hemmer, S. Wöhrl, G. Sesztak-Greinecker, R. Jarisch, and F. Wantke. 2014. Clinical characteristics and risk profile of patients with elevated baseline serum tryptase. Allergol. Immunopathol. (Madr.). 42:544-552. https://doi.org/10.1016/j.aller.2014.05.002

Frischmeyer-Guerrerio, P.A., A.L. Guerrerio, G. Oswald, K. Chichester, L. Myers, M.K. Halushka, M. Oliva-Hemker, R.A. Wood, and H.C. Dietz. 2013. TGF $\beta$ receptor mutations impose a strong predisposition for human allergic disease. Sci. Transl. Med. 5:195ra94. https://doi.org/10 $.1126 /$ scitranslmed.3006448

Galli, S.J., and M. Tsai. 2010. Mast cells in allergy and infection: versatile effector and regulatory cells in innate and adaptive immunity. Eur. J. Immunol. 40:1843-1851. https://doi.org/10.1002/eji.201040559

Gandhi, C., C. Healy, A.A. Wanderer, and H.M. Hoffman. 2009. Familial atypical cold urticaria: description of a new hereditary disease. J. Allergy Clin. Immunol. 124:1245-1250. https://doi.org/10.1016/j.jaci.2009.09.035

Gell, P.G.H., and R.R.A. Coombs, editors. 1963. Clinical aspects of immunology. Blackwell, Oxford.

Glocker, E.O., D. Kotlarz, K. Boztug, E.M. Gertz, A.A. Schäffer, F. Noyan, M. Perro, J. Diestelhorst, A. Allroth, D. Murugan, et al. 2009. Inflammatory bowel disease and mutations affecting the interleukin-10 receptor. $N$. Engl. J. Med. 361:2033-2045. https://doi.org/10.1056/NEJMoa0907206

Glocker, E.O., N. Frede, M. Perro, N. Sebire, M. Elawad, N. Shah, and B. Grimbacher. 2010. Infant colitis--it's in the genes. Lancet. 376:1272. https:// doi.org/10.1016/S0140-6736(10)61008-2

Gonzalez-Quintela, A., L. Vizcaino, F. Gude, J. Rey, L. Meijide, C. Fernandez-Merino, A. Linneberg, and C. Vidal. 2010. Factors influencing serum total tryptase concentrations in a general adult population. Clin. Chem. Lab. Med. 48:701-706. https://doi.org/10.1515/CCLM.2010.124

Greil, J., T. Rausch, T. Giese, O.R. Bandapalli, V. Daniel, I. Bekeredjian-Ding, A.M. Stütz, C. Drees, S. Roth, J. Ruland, et al. 2013. Whole-exome sequencing links caspase recruitment domain 11 (CARD11) inactivation to severe combined immunodeficiency.J. Allergy Clin. Immunol. 131:13761383.e3. https://doi.org/10.1016/j.jaci.2013.02.012

Hamilton, K.S., B. Phong, C. Corey, J. Cheng, B. Gorentla, X. Zhong, S. Shiva, and L.P. Kane. 2014. T cell receptor-dependent activation of mTOR signaling in T cells is mediated by Carmal and MALT1, but not Bcl10. Sci. Signal. 7:ra55. https://doi.org/10.1126/scisignal.2005169

Haribhai, D., J.B. Williams, S. Jia, D. Nickerson, E.G. Schmitt, B. Edwards, J. Ziegelbauer, M. Yassai, S.H. Li, L.M. Relland, et al. 2011. A requisite role for induced regulatory $\mathrm{T}$ cells in tolerance based on expanding antigen receptor diversity. Immunity. 35:109-122. https://doi.org/10.1016/j immuni.2011.03.029 
Hershey, G.K., M.F. Friedrich, L.A. Esswein, M.L. Thomas, and T.A. Chatila. 1997. The association of atopy with a gain-of-function mutation in the alpha subunit of the interleukin-4 receptor. N. Engl. J. Med. 337:17201725. https://doi.org/10.1056/NEJM199712113372403

Hirota, T., A. Takahashi, M. Kubo, T. Tsunoda, K. Tomita, M. Sakashita, T. Yamada, S. Fujieda, S. Tanaka, S. Doi, et al. 2012. Genome-wide association study identifies eight new susceptibility loci for atopic dermatitis in the Japanese population. Nat. Genet. 44:1222-1226. https://doi.org/10 $.1038 /$ ng. 2438

Holland, S.M., F.R. DeLeo, H.Z. Elloumi, A.P. Hsu, G. Uzel, N. Brodsky, A.F. Freeman, A. Demidowich, J. Davis, M.L. Turner, et al. 2007. STAT3 mutations in the hyper-IgE syndrome. N. Engl. J. Med. 357:1608-1619. https:// doi.org/10.1056/NEJMoa073687

Hosken, N.A., K. Shibuya, A.W. Heath, K.M. Murphy, and A. O'Garra. 1995. The effect of antigen dose on CD4 + Thelper cell phenotype development in a $\mathrm{T}$ cell receptor-alpha beta-transgenic model. J. Exp. Med. 182:1579-1584. https://doi.org/10.1084/jem.182.5.1579

Howell, M.D., B.E. Kim, P. Gao, A.V. Grant, M. Boguniewicz, A. Debenedetto, L. Schneider, L.A. Beck, K.C. Barnes, and D.Y. Leung. 2007. Cytokine modulation of atopic dermatitis filaggrin skin expression. J. Allergy Clin. Immunol. 120:150-155. https://doi.org/10.1016/j.jaci.2007.04.031

Hox, V., M.P. O'Connell, J.J. Lyons, P. Sackstein, T. Dimaggio, N. Jones, C. Nelson, M. Boehm, S.M. Holland, A.F. Freeman, et al. 2016. Diminution of signal transducer and activator of transcription 3 signaling inhibits vascular permeability and anaphylaxis. J. Allergy Clin. Immunol. 138:187-199. https://doi.org/10.1016/j.jaci.2015.11.024

Huang, Y.S., N.Y. Chiang, C.H. Hu, C.C. Hsiao, K.F. Cheng, W.P. Tsai, S. Yona, M. Stacey, S. Gordon, G.W. Chang, and H.H. Lin. 2012. Activation of myeloid cell-specific adhesion class $G$ protein-coupled receptor EMR2 via ligation-induced translocation and interaction of receptor subunits in lipid raft microdomains. Mol. Cell. Biol. 32:1408-1420. https://doi.org/ 10.1128/MCB.06557-11

Humblet-Baron, S., B. Sather, S. Anover, S. Becker-Herman, D.J. Kasprowicz, S. Khim, T. Nguyen, K. Hudkins-Loya, C.E. Alpers, S.F. Ziegler, et al. 2007. Wiskott-Aldrich syndrome protein is required for regulatory $\mathrm{T}$ cell homeostasis. J. Clin. Invest. 117:407-418. https://doi.org/10.1172/JCI29539

Hvid, M., C. Vestergaard, K. Kemp, G.B. Christensen, B. Deleuran, and M. Deleuran. 2011. IL-25 in atopic dermatitis: a possible link between inflammation and skin barrier dysfunction? J. Invest. Dermatol. 131:150157. https://doi.org/10.1038/jid.2010.277

Irvine, A.D., W.H. McLean, and D.Y. Leung. 2011. Filaggrin mutations associated with skin and allergic diseases. N. Engl. J. Med. 365:1315-1327. https://doi.org/10.1056/NEJMra1011040

Ishida-Yamamoto, A., C. Deraison, C. Bonnart, E. Bitoun, R. Robinson, T.J. O'Brien, K. Wakamatsu, S. Ohtsubo, H. Takahashi, Y. Hashimoto, et al. 2005. LEKTI is localized in lamellar granules, separated from KLK5 and KLK7, and is secreted in the extracellular spaces of the superficial stratum granulosum.J. Invest. Dermatol. 124:360-366. https://doi.org/10 $.1111 /$ j.0022-202X.2004.23583.x

Jabara, H.H., T. Ohsumi, J. Chou, M.J. Massaad, H. Benson, A. Megarbane, E. Chouery, R. Mikhael, O. Gorka, A. Gewies, et al. 2013. A homozygous mucosa-associated lymphoid tissue 1 (MALT1) mutation in a family with combined immunodeficiency. J. Allergy Clin. Immunol. 132:151-158. https://doi.org/10.1016/j.jaci.2013.04.047

Jakob, T., G.V. Köllisch, M. Howaldt, M. Bewersdorff, B. Rathkolb, M.L. Müller, N. Sandholzer, L. Nitschke, M. Schiemann, M. Mempel, et al. 2008. Novel mouse mutants with primary cellular immunodeficiencies generated by genome-wide mutagenesis. J. Allergy Clin. Immunol. 121:179-184 . e7. https://doi.org/10.1016/j.jaci.2007.07.018

Janssen, E., H. Morbach, S. Ullas, J.M. Bannock, C. Massad, L. Menard, I. Barlan, G. Lefranc, H. Su, M. Dasouki, et al. 2014. Dedicator of cytokinesis 8-deficient patients have a breakdown in peripheral B-cell tolerance and defective regulatory T cells. J. Allergy Clin. Immunol. 134:1365-1374. https://doi.org/10.1016/j.jaci.2014.07.042

Janssen, E., M. Tohme, M. Hedayat, M. Leick, S. Kumari, N. Ramesh, M.J. Massaad, S. Ullas, V. Azcutia, C.C. Goodnow, et al. 2016. A DOCK8-WIP-WASp complex links $\mathrm{T}$ cell receptors to the actin cytoskeleton. J. Clin. Invest. 126:3837-3851. https://doi.org/10.1172/JCI85774

Janssen, E., S. Kumari, M. Tohme, S. Ullas, V. Barrera, J.M. Tas, M. Castillo-Rama, R.T. Bronson, S.M. Usmani, D.J. Irvine, et al. 2017. DOCK8 enforces immunological tolerance by promoting IL-2 signaling and immune synapse formation in Tregs. JCI Insight. 2:e94298. https://doi .org/10.1172/jci.insight. 94298

Johansson, S.G., T. Bieber, R. Dahl, P.S. Friedmann, B.Q. Lanier, R.F. Lockey, C. Motala, J.A. Ortega Martell, T.A. Platts-Mills, J. Ring, et al. 2004. Revised nomenclature for allergy for global use: Report of the Nomenclature Review Committee of the World Allergy Organization, October 2003. J. Allergy Clin. Immunol. 113:832-836. https://doi.org/10.1016/j.jaci.2003 .12 .591

Jonca, N., E.A. Leclerc, C. Caubet, M. Simon, M. Guerrin, and G. Serre. 2011. Corneodesmosomes and corneodesmosin: from the stratum corneum cohesion to the pathophysiology of genodermatoses. Eur. J. Dermatol. 21(Suppl 2):35-42.

Jorritsma, P.J., J.L. Brogdon, and K. Bottomly. 2003. Role of TCR-induced extracellular signal-regulated kinase activation in the regulation of early IL-4 expression in naive CD4+ T cells. J. Immunol. 170:2427-2434. https://doi .org/10.4049/jimmunol.170.5.2427

Josefowicz, S.Z., R.E. Niec, H.Y. Kim, P. Treuting, T. Chinen, Y. Zheng, D.T. Umetsu, and A.Y. Rudensky. 2012. Extrathymically generated regulatory T cells control mucosal TH2 inflammation. Nature. 482:395-399. https:// doi.org/10.1038/nature10772

Joshi, A.Y., E.K. Ham, N.B. Shah, X. Dong, S.P. Khan, and R.S. Abraham. 2012. Atypical Omenn Syndrome due to Adenosine Deaminase Deficiency. Case Reports Immunol. 2012:919241. https://doi.org/10.1155/2012/919241

Jun, J.E., L.E. Wilson, C.G. Vinuesa, S. Lesage, M. Blery, L.A. Miosge, M.C. Cook, E.M. Kucharska, H. Hara, J.M. Penninger, et al. 2003. Identifying the MAGUK protein Carma-1 as a central regulator of humoral immune responses and atopy by genome-wide mouse mutagenesis. Immunity. 18:751-762. https://doi.org/10.1016/S1074-7613(03)00141-9

Jungersted, J.M., H. Scheer, M. Mempel, H. Baurecht, L. Cifuentes, J.K. Høgh, L.I. Hellgren, G.B. Jemec, T. Agner, and S. Weidinger. 2010. Stratum corneum lipids, skin barrier function and filaggrin mutations in patients with atopic eczema. Allergy. 65:911-918. https://doi.org/10.1111/j.1398 $-9995.2010 .02326 . x$

Kahr, W.H., F.G. Pluthero, A. Elkadri, N. Warner, M. Drobac, C.H. Chen, R.W. Lo, L. Li, R. Li, Q. Li, et al. 2017. Loss of the Arp2/3 complex component ARPC1B causes platelet abnormalities and predisposes to inflammatory disease. Nat. Commun. 8:14816. https://doi.org/10.1038/ncomms14816

Kanai, T., J. Jenks, and K.C. Nadeau. 2012. The STAT5b Pathway Defect and Autoimmunity. Front. Immunol. 3:234. https://doi.org/10.3389/fimmu .2012 .00234

Kane, A., A. Lau, R. Brink, S.G. Tangye, and E.K. Deenick. 2016. B-cell-specific STAT3 deficiency: Insight into the molecular basis of autosomal-dominant hyper-IgE syndrome. J. Allergy Clin. Immunol. 138:1455-1458.e3. https://doi.org/10.1016/j.jaci.2016.05.018

Kawakami, T., T. Ando, and Y. Kawakami. 2015. Hypothetical Atopic Dermatitis-Myeloproliferative Neoplasm Syndrome. Front. Immunol. 6:434. https://doi.org/10.3389/fimmu.2015.00434

Ke, H., J.U. Kazi, H. Zhao, and J. Sun. 2016. Germline mutations of KIT in gastrointestinal stromal tumor (GIST) and mastocytosis. Cell Biosci. 6:55. https://doi.org/10.1186/s13578-016-0120-8

Keller, B., I. Zaidman, O.S. Yousefi, D. Hershkovitz, J. Stein, S. Unger, K. Schachtrup, M. Sigvardsson, A.A. Kuperman, A. Shaag, et al. 2016. Early onset combined immunodeficiency and autoimmunity in patients with loss-of-function mutation in LAT. J. Exp. Med. 213:1185-1199. https://doi .org $/ 10.1084 /$ jem. 20151110

Kezic, S., G.M. O’Regan, R. Lutter, I. Jakasa, E.S. Koster, S. Saunders, P. Caspers, P.M. Kemperman, G.J. Puppels, A. Sandilands, et al. 2012. Filaggrin lossof-function mutations are associated with enhanced expression of IL-1 cytokines in the stratum corneum of patients with atopic dermatitis and in a murine model of filaggrin deficiency. J. Allergy Clin. Immunol. 129:1031-1039.el. https://doi.org/10.1016/j.jaci.2011.12.989

Kotlarz, D., R. Beier, D. Murugan, J. Diestelhorst, O. Jensen, K. Boztug, D. Pfeifer, H. Kreipe, E.D. Pfister, U. Baumann, et al. 2012. Loss of interleukin-10 signaling and infantile inflammatory bowel disease: implications for diagnosis and therapy. Gastroenterology. 143:347-355. https://doi.org/ 10.1053/j.gastro.2012.04.045

Kottke, M.D., E. Delva, and A.P. Kowalczyk. 2006. The desmosome: cell science lessons from human diseases. J. Cell Sci. 119:797-806. https://doi.org/10 $.1242 /$ jcs. 02888

Kreins, A.Y., M.J. Ciancanelli, S. Okada, X.F. Kong, N. Ramírez-Alejo, S.S. Kilic, J. El Baghdadi, S. Nonoyama, S.A. Mahdaviani, F. Ailal, et al. 2015. Human TYK2 deficiency: Mycobacterial and viral infections without hyper-IgE syndrome. J. Exp. Med. 212:1641-1662. https://doi.org/10 $.1084 /$ jem.20140280

Kucharewicz, I., A. Bodzenta-Lukaszyk, W. Szymanski, B. Mroczko, and M. Szmitkowski. 2007. Basal serum tryptase level correlates with severity of hymenoptera sting and age. J. Investig. Allergol. Clin. Immunol. 17:65-69. 
Küçük, C., B. Jiang, X. Hu, W. Zhang, J.K. Chan, W. Xiao, N. Lack, C. Alkan, J.C. Williams, K.N. Avery, et al. 2015. Activating mutations of STAT5B and STAT3 in lymphomas derived from $\gamma \delta$-T or NK cells. Nat. Commun. 6:6025. https://doi.org/10.1038/ncomms7025

Kuijpers, T.W., A.T.J. Tool, I. van der Bijl, M. de Boer, M. van Houdt, I.M. de Cuyper, D. Roos, F. van Alphen, K. van Leeuwen, E.L. Cambridge, et al. 2017. Combined immunodeficiency with severe inflammation and allergy caused by ARPC1B deficiency. J. Allergy Clin. Immunol. 140:273277.e10. https://doi.org/10.1016/j.jaci.2016.09.061

Lanzi, G., D. Moratto, D. Vairo, S. Masneri, O. Delmonte, T. Paganini, S. Parolini, G. Tabellini, C. Mazza, G. Savoldi, et al. 2012. A novel primary human immunodeficiency due to deficiency in the WASP-interacting protein WIP. J. Exp. Med. 209:29-34. https://doi.org/10.1084/jem.20110896

Lawrence, M.G., J.S. Barber, R.A. Sokolic, E.K. Garabedian, A.N. Desai, M. O’Brien, N. Jones, P. Bali, M.S. Hershfield, K.D. Stone, et al. 2013. Elevated IgE and atopy in patients treated for early-onset ADA-SCID.J. Allergy Clin. Immunol. 132:1444-1446.e5. https://doi.org/10.1016/j.jaci.2013.05.040

Lexmond, W.S., J.A. Goettel, J.J. Lyons, J. Jacobse, M.M. Deken, M.G. Lawrence, T.H. DiMaggio, D. Kotlarz, E. Garabedian, P. Sackstein, et al. 2016. FOXP3+ Tregs require WASP to restrain Th2-mediated food allergy. J. Clin. Invest. 126:4030-4044. https://doi.org/10.1172/JCI85129

Liang, Y., M. Cucchetti, R. Roncagalli, T. Yokosuka, A. Malzac, E. Bertosio, J. Imbert, I.J. Nijman, M. Suchanek, T. Saito, et al. 2013. The lymphoid lineage-specific actin-uncapping protein Rltpr is essential for costimulation via CD28 and the development of regulatory T cells. Nat. Immunol. 14:858-866. https://doi.org/10.1038/ni.2634

Lindsay, M.E., and H.C. Dietz. 2014. The genetic basis of aortic aneurysm. Cold Spring Harb. Perspect. Med. 4:a015909. https://doi.org/10.1101/ cshperspect.a015909

Loeys, B.L., U. Schwarze, T. Holm, B.L. Callewaert, G.H. Thomas, H. Pannu, J.F. De Backer, G.L. Oswald, S. Symoens, S. Manouvrier, et al. 2006. Aneurysm syndromes caused by mutations in the TGF-beta receptor. N. Engl. J. Med. 355:788-798. https://doi.org/10.1056/NEJMoa055695

Lyons, J.J., G. Sun, K.D. Stone, C. Nelson, L. Wisch, M. O’Brien, N. Jones, A. Lindsley, H.D. Komarow, Y. Bai, et al. 2014. Mendelian inheritance of elevated serum tryptase associated with atopy and connective tissue abnormalities. J. Allergy Clin. Immunol. 133:1471-1474. https://doi.org/10 $.1016 /$ j.jaci.2013.11.039

Lyons, J.J., X. Yu, J.D. Hughes, Q.T. Le, A. Jamil, Y. Bai, N. Ho, M. Zhao, Y. Liu, M.P. O'Connell, et al. 2016. Elevated basal serum tryptase identifies a multisystem disorder associated with increased TPSAB1 copy number. Nat. Genet. 48:1564-1569. https://doi.org/10.1038/ng.3696

Lyons, J.J., Y. Liu, C.A. Ma, X. Yu, M.P. O'Connell, M.G. Lawrence, Y. Zhang, K. Karpe, M. Zhao, A.M. Siegel, et al. 2017. ERBIN deficiency links STAT3 and TGF- $\beta$ pathway defects with atopy in humans. J. Exp. Med. 214:669680. https://doi.org/10.1084/jem.2016143503082017c

Ma, C.S., N. Wong, G. Rao, D.T. Avery, J. Torpy, T. Hambridge, J. Bustamante, S. Okada, J.L. Stoddard, E.K. Deenick, et al. 2015. Monogenic mutations differentially affect the quantity and quality of $\mathrm{T}$ follicular helper cells in patients with human primary immunodeficiencies. J. Allergy Clin. Immunol. 136:993-1006.e1. https://doi.org/10.1016/j.jaci.2015.05.036

Ma, C.A., J.R. Stinson, Y. Zhang, J.K. Abbott, M.A. Weinreich, P.J. Hauk, P.R. Reynolds, J.J. Lyons, C.G. Nelson, E. Ruffo, et al. 2017a. Germline hypomorphic CARD11 mutations in severe atopic disease. Nat. Genet. 49:11921201. https://doi.org/10.1038/ng.3898

Ma, C.A., L. Xi, B. Cauff, A. DeZure, A.F. Freeman, S. Hambleton, G. Kleiner, T.R. Leahy, M. O'Sullivan, M. Makiya, et al. 2017b. Somatic STAT5b gainof-function mutations in early onset nonclonal eosinophilia, urticaria, dermatitis, and diarrhea. Blood. 129:650-653. https://doi.org/10.1182/ blood-2016-09-737817

Maillard, M.H., V. Cotta-de-Almeida, F. Takeshima, D.D. Nguyen, P. Michetti, C. Nagler, A.K. Bhan, and S.B. Snapper. 2007. The Wiskott-Aldrich syndrome protein is required for the function of CD4(+)CD25(+)Foxp3(+) regulatory T cells. J. Exp. Med. 204:381-391. https://doi.org/10.1084/jem .20061338

Marangoni, F., S. Trifari, S. Scaramuzza, C. Panaroni, S. Martino, L.D. Notarangelo, Z. Baz, A. Metin, F. Cattaneo, A. Villa, et al. 2007. WASP regulates suppressor activity of human and murine CD4(+)CD25(+)FOXP3(+) natural regulatory T cells. J. Exp. Med. 204:369-380. https://doi.org/10 $.1084 /$ jem.20061334

Mark, B.J., B.A. Becker, D.R. Halloran, A.F. Bree, R. Sindwani, M.D. Fete, K.J. Motil, S.W. Srun, and T.J. Fete. 2012. Prevalence of atopic disorders and immunodeficiency in patients with ectodermal dysplasia syndromes. Ann. Allergy Asthma Immunol. 108:435-438. https://doi.org/10.1016/j .anai.2012.04.010
Markert, M.L., M.J. Alexieff, J. Li, M. Sarzotti, D.A. Ozaki, B.H. Devlin, G.D. Sempowski, M.E. Rhein, P. Szabolcs, L.P. Hale, et al. 2004. Complete DiGeorge syndrome: development of rash, lymphadenopathy, and oligoclonal T cells in 5 cases. J. Allergy Clin. Immunol. 113:734-741. https:// doi.org/10.1016/j.jaci.2004.01.766

Massaad, M.J., B. Cangemi, W. Al-Herz, G. LeFranc, A. Freeman, S. Baxi, S. Keles, A. Metin, M. Dasouki, A. Sobh, et al. 2017. DOCK8 and STAT3 dependent inhibition of IgE isotype switching by TLR9 ligation in human B cells. Clin. Immunol. 183:263-265. https://doi.org/10.1016/j .clim.2017.08.020

McAleer, M.A., E. Pohler, F.J. Smith, N.J. Wilson, C. Cole, S. MacGowan, J.L. Koetsier, L.M. Godsel, R.M. Harmon, R. Gruber, et al. 2015. Severe dermatitis, multiple allergies, and metabolic wasting syndrome caused by a novel mutation in the $\mathrm{N}$-terminal plakin domain of desmoplakin. J. Allergy Clin. Immunol. 136:1268-1276. https://doi.org/10.1016/j.jaci.2015 .05 .002

McKinnon, M.L., J. Rozmus, S.Y. Fung, A.F. Hirschfeld, K.L. Del Bel, L. Thomas, N. Marr, S.D. Martin, A.K. Marwaha, J.J. Priatel, et al. 2014. Combined immunodeficiency associated with homozygous MALT1 mutations. J. Allergy Clin. Immunol. 133:1458-1462.e7. https://doi.org/10.1016/j.jaci .2013.10.045

Meiler, F., J. Zumkehr, S. Klunker, B. Rückert, C.A. Akdis, and M. Akdis. 2008 In vivo switch to IL-10-secreting $\mathrm{T}$ regulatory cells in high dose allergen exposure. J. Exp. Med. 205:2887-2898. https://doi.org/10.1084/jem .20080193

Miajlovic, H., P.G. Fallon, A.D. Irvine, and T.J. Foster. 2010. Effect of filaggrin breakdown products on growth of and protein expression by Staphylococcus aureus.J. Allergy Clin. Immunol. 126:1184-1190.e3. https://doi.org/ 10.1016/j.jaci.2010.09.015

Milner, J.D., J.M. Ward, A. Keane-Myers, and W.E. Paul. 2007. Lymphopenic mice reconstituted with limited repertoire $\mathrm{T}$ cells develop severe, multiorgan, Th2-associated inflammatory disease. Proc. Natl. Acad. Sci. USA. 104:576-581. https://doi.org/10.1073/pnas.0610289104

Milner, J.D., N. Fazilleau, M. McHeyzer-Williams, and W. Paul. 2010. Cutting edge: lack of high affinity competition for peptide in polyclonal CD4+ responses unmasks IL-4 production.J. Immunol. 184:6569-6573. https:// doi.org/10.4049/jimmunol.1000674

Milner, J.D., T.P. Vogel, L. Forbes, C.A. Ma, A. Stray-Pedersen, J.E. Niemela, J.J. Lyons, K.R. Engelhardt, Y. Zhang, N. Topcagic, et al. 2015. Early-onset lymphoproliferation and autoimmunity caused by germline STAT3 gainof-function mutations. Blood. 125:591-599. https://doi.org/10.1182/blood -2014-09-602763

Minegishi, Y., M. Saito, T. Morio, K. Watanabe, K. Agematsu, S. Tsuchiya, H. Takada, T. Hara, N. Kawamura, T. Ariga, et al. 2006. Human tyrosine kinase 2 deficiency reveals its requisite roles in multiple cytokine signals involved in innate and acquired immunity. Immunity. 25:745-755. https://doi.org/10.1016/j.immuni.2006.09.009

Minegishi, Y., M. Saito, S. Tsuchiya, I. Tsuge, H. Takada, T. Hara, N. Kawamura, T. Ariga, S. Pasic, O. Stojkovic, et al. 2007. Dominant-negative mutations in the DNA-binding domain of STAT3 cause hyper-IgE syndrome. Nature. 448:1058-1062. https://doi.org/10.1038/nature06096

Mingueneau, M., R. Roncagalli, C. Grégoire, A. Kissenpfennig, A. Miazek, C. Archambaud, Y. Wang, P. Perrin, E. Bertosio, A. Sansoni, et al. 2009. Loss of the LAT adaptor converts antigen-responsive $\mathrm{T}$ cells into pathogenic effectors that function independently of the T cell receptor. Immunity. 31:197-208. https://doi.org/10.1016/j.immuni.2009.05.013

Morgan, A.W., S.B. Pearson, S. Davies, H.C. Gooi, and H.A. Bird. 2007. Asthma and airways collapse in two heritable disorders of connective tissue. Ann. Rheum. Dis. 66:1369-1373. https://doi.org/10.1136/ard.2006.062224

Nadeau, K., V. Hwa, and R.G. Rosenfeld. 2011. STAT5b deficiency: an unsuspected cause of growth failure, immunodeficiency, and severe pulmonary disease.J. Pediatr. 158:701-708. https://doi.org/10.1016/j.jpeds.2010 .12 .042

Nakaya, M., Y. Xiao, X. Zhou, J.H. Chang, M. Chang, X. Cheng, M. Blonska, X. Lin, and S.C. Sun. 2014. Inflammatory $\mathrm{T}$ cell responses rely on amino acid transporter ASCT2 facilitation of glutamine uptake and mTORC1 kinase activation. Immunity. 40:692-705. https://doi.org/10.1016/j .immuni.2014.04.007

Nelson, H.S. 2013. Introducing atopy. In Landmark Papers in Allergy: Seminal Papers in Allergy with Expert Commentaries. A. Sheikh, T. Platts-Mills, and A. Worth, editors. Oxford University Press, Oxford, UK. 56-58.

Nishida, T., S. Hirota, M. Taniguchi, K. Hashimoto, K. Isozaki, H. Nakamura, Y. Kanakura, T. Tanaka, A. Takabayashi, H. Matsuda, and Y. Kitamura. 1998. Familial gastrointestinal stromal tumours with germline mutation of the KIT gene. Nat. Genet. 19:323-324. https://doi.org/10.1038/1209 
Noval Rivas, M., O.T. Burton, P. Wise, L.M. Charbonnier, P. Georgiev, H.C. Oettgen, R. Rachid, and T.A. Chatila. 2015. Regulatory T cell reprogramming toward a Th2-cell-like lineage impairs oral tolerance and promotes food allergy. Immunity. 42:512-523. https://doi.org/10.1016/j.immuni.2015.02 .004

Ochs, H.D. 2009. Mutations of the Wiskott-Aldrich Syndrome Protein affect protein expression and dictate the clinical phenotypes. Immunol. Res. 44:84-88. https://doi.org/10.1007/s12026-008-8084-3

Oetjen, L.K., M.R. Mack, J. Feng, T.M. Whelan, H. Niu, C.J. Guo, S. Chen, A.M. Trier, A.Z. Xu, S.V. Tripathi, et al. 2017. Sensory Neurons Co-opt Classical Immune Signaling Pathways to Mediate Chronic Itch. Cell. 171:217-228. el3. https://doi.org/10.1016/j.cell.2017.08.006

Ogawa, K., Y. Tanaka, T. Uruno, X. Duan, Y. Harada, F. Sanematsu, K. Yamamura, M. Terasawa, A. Nishikimi, J.F. Côté, and Y. Fukui. 2014. DOCK5 functions as a key signaling adaptor that links FceRI signals to microtubule dynamics during mast cell degranulation. J. Exp. Med. 211:14071419. https://doi.org/10.1084/jem.20131926

Oji, V., K.M. Eckl, K. Aufenvenne, M. Nätebus, T. Tarinski, K. Ackermann, N. Seller, D. Metze, G. Nürnberg, R. Fölster-Holst, et al. 2010. Loss of corneodesmosin leads to severe skin barrier defect, pruritus, and atopy: unraveling the peeling skin disease. Am. J. Hum. Genet. 87:274-281. https://doi.org/10.1016/j.ajhg.2010.07.005

Olson, M.R., F.F. Verdan, M.M. Hufford, A.L. Dent, and M.H. Kaplan. 2016. STAT3 Impairs STAT5 Activation in the Development of IL-9-Secreting T Cells. J. Immunol. 196:3297-3304. https://doi.org/10.4049/jimmunol .1501801

Ombrello, M.J., E.F. Remmers, G. Sun, A.F. Freeman, S. Datta, P. Torabi-Parizi, N. Subramanian, T.D. Bunney, R.W. Baxendale, M.S. Martins, et al. 2012. Cold urticaria, immunodeficiency, and autoimmunity related to PLCG2 deletions. N. Engl. J. Med. 366:330-338. https://doi.org/10.1056/ NEJMoa1102140

Picard, C., S. Dogniaux, K. Chemin, Z. Maciorowski, A. Lim, F. Mazerolles, F. Rieux-Laucat, M.C. Stolzenberg, M. Debre, J.P. Magny, et al. 2009. Hypomorphic mutation of ZAP70 in human results in a late onset immunodeficiency and no autoimmunity. Eur. J. Immunol. 39:1966-1976. https:// doi.org/10.1002/eji.200939385

Pivniouk, V.I., S.B. Snapper, A. Kettner, H. Alenius, D. Laouini, H. Falet, J. Hartwig, F.W. Alt, and R.S. Geha. 2003. Impaired signaling via the high-affinity IgE receptor in Wiskott-Aldrich syndrome protein-deficient mast cells. Int. Immunol. 15:1431-1440. https://doi.org/10.1093/ intimm/dxg148

Punwani, D., H. Wang, A.Y. Chan, M.J. Cowan, J. Mallott, U. Sunderam, M. Mollenauer, R. Srinivasan, S.E. Brenner, A. Mulder, et al. 2015. Combined immunodeficiency due to MALT1 mutations, treated by hematopoietic cell transplantation. J. Clin. Immunol. 35:135-146. https://doi.org/10 .1007/s10875-014-0125-1

Rajala, H.L., S. Eldfors, H. Kuusanmäki, A.J. van Adrichem, T. Olson, S. Lagström, E.I. Andersson, A. Jerez, M.J. Clemente, Y. Yan, et al. 2013. Discovery of somatic STAT5b mutations in large granular lymphocytic leukemia. Blood. 121:4541-4550. https://doi.org/10.1182/blood-2012-12 $-474577$

Ramsdell, F., and S.F. Ziegler. 2014. FOXP3 and scurfy: how it all began. Nat. Rev. Immunol. 14:343-349. https://doi.org/10.1038/nri3650

Rawson, R., T. Yang, R.O. Newbury, M. Aquino, A. Doshi, B. Bell, D.H. Broide, R. Dohil, R. Kurten, and S.S. Aceves. 2016. TGF- $\beta 1$-induced PAI-1 contributes to a profibrotic network in patients with eosinophilic esophagitis. J. Allergy Clin. Immunol. 138:791-800.e4.https://doi.org/10.1016/j.jaci.2016 .02 .028

Roncagalli, R., M. Cucchetti, N. Jarmuzynski, C. Grégoire, E. Bergot, S. Audebert, E. Baudelet, M.G. Menoita, A. Joachim, S. Durand, et al. 2016. The scaffolding function of the RLTPR protein explains its essential role for CD28 co-stimulation in mouse and human T cells. J. Exp. Med. 213:24372457. https://doi.org/10.1084/jem.20160579

Sahiner, U.M., S.T. Yavuz, B. Buyuktiryaki, O. Cavkaytar, E.A. Yilmaz, A. Tuncer, and C. Sackesen. 2014. Serum basal tryptase may be a good marker for predicting the risk of anaphylaxis in children with food allergy. Allergy. 69:265-268. https://doi.org/10.1111/all.12317

Samuelov, L., O. Sarig, R.M. Harmon, D. Rapaport, A. Ishida-Yamamoto, O. Isakov, J.L. Koetsier, A. Gat, I. Goldberg, R. Bergman, et al. 2013. Desmoglein 1 deficiency results in severe dermatitis, multiple allergies and metabolic wasting. Nat. Genet. 45:1244-1248. https://doi.org/10.1038/ng.2739

Sandilands, A., A. Terron-Kwiatkowski, P.R. Hull, G.M. O’Regan, T.H. Clayton, R.M. Watson, T. Carrick, A.T. Evans, H. Liao, Y. Zhao, et al. 2007. Comprehensive analysis of the gene encoding filaggrin uncovers prevalent and rare mutations in ichthyosis vulgaris and atopic eczema. Nat. Genet. 39:650-654. https://doi.org/10.1038/ng2020

Sandilands, A., C. Sutherland, A.D. Irvine, and W.H. McLean. 2009. Filaggrin in the frontline: role in skin barrier function and disease. J. Cell Sci. 122:1285-1294. https://doi.org/10.1242/jcs.033969

Sassi, A., S. Lazaroski, G. Wu, S.M. Haslam, M. Fliegauf, F. Mellouli, T. Patiroglu, E. Unal, M.A. Ozdemir, Z. Jouhadi, et al. 2014. Hypomorphic homozygous mutations in phosphoglucomutase 3 (PGM3) impair immunity and increase serum IgE levels. J. Allergy Clin. Immunol. 133:1410-1419.e13. https://doi.org/10.1016/j.jaci.2014.02.025

Schalkwijk, J., M.C. Zweers, P.M. Steijlen, W.B. Dean, G. Taylor, I.M. van Vlijmen, B. van Haren, W.L. Miller, and J. Bristow. 2001. A recessive form of the Ehlers-Danlos syndrome caused by tenascin-X deficiency. N. Engl.J. Med. 345:1167-1175. https://doi.org/10.1056/NEJMoa002939

Schober, T., T. Magg, M. Laschinger, M. Rohlfs, N.D. Linhares, J. Puchalka, T. Weisser, K. Fehlner, J. Mautner, C. Walz, et al. 2017. A human immunodeficiency syndrome caused by mutations in CARMIL2. Nat. Commun. 8:14209. https://doi.org/10.1038/ncomms14209

Seguchi, T., C.Y. Cui, S. Kusuda, M. Takahashi, K. Aisu, and T. Tezuka. 1996. Decreased expression of filaggrin in atopic skin. Arch. Dermatol. Res. 288:442-446. https://doi.org/10.1007/BF02505232

Shearer, W.T., E. Dunn, L.D. Notarangelo, C.C. Dvorak, J.M. Puck, B.R. Logan, L.M. Griffith, D.B. Kohn, R.J. O'Reilly, T.A. Fleisher, et al. 2014. Establishing diagnostic criteria for severe combined immunodeficiency disease (SCID), leaky SCID, and Omenn syndrome: the Primary Immune Deficiency Treatment Consortium experience. J. Allergy Clin. Immunol. 133:1092-1098. https://doi.org/10.1016/j.jaci.2013.09.044

Siberry, G.K., E. Leister, D.L. Jacobson, S.B. Foster, G.R. Seage III, S.E. Lipshultz, M.E. Paul, M. Purswani, A.A. Colin, G. Scott, and W.T. Shearer. 2012. Increased risk of asthma and atopic dermatitis in perinatally HIV-infected children and adolescents. Clin. Immunol. 142:201-208. https://doi .org/10.1016/j.clim.2011.10.005

Siegel, A.M., K.D. Stone, G. Cruse, M.G. Lawrence, A. Olivera, M.Y. Jung, J.S. Barber, A.F. Freeman, S.M. Holland, M. O'Brien, et al. 2013. Diminished allergic disease in patients with STAT3 mutations reveals a role for STAT3 signaling in mast cell degranulation. J. Allergy Clin. Immunol. 132:1388-1396.e3. https://doi.org/10.1016/j.jaci.2013.08.045

Simpson, E.L., J.R. Chalmers, J.M. Hanifin, K.S. Thomas, M.J. Cork, W.H. McLean, S.J. Brown, Z. Chen, Y. Chen, and H.C. Williams. 2014. Emollient enhancement of the skin barrier from birth offers effective atopic dermatitis prevention. J. Allergy Clin. Immunol. 134:818-823. https://doi .org/10.1016/j.jaci.2014.08.005

Singh, A.K., A. Eken, D. Hagin, K. Komal, G. Bhise, A. Shaji, T. Arkatkar, S.W. Jackson, E. Bettelli, T.R. Torgerson, and M. Oukka. 2017. DOCK8 regulates fitness and function of regulatory $\mathrm{T}$ cells through modulation of IL-2 signaling. JCI Insight. 2:e94275. https://doi.org/10.1172/jci.insight .94275

Smith, F.J., A.D. Irvine, A. Terron-Kwiatkowski, A. Sandilands, L.E. Campbell, Y. Zhao, H. Liao, A.T. Evans, D.R. Goudie, S. Lewis-Jones, et al. 2006. Lossof-function mutations in the gene encoding filaggrin cause ichthyosis vulgaris. Nat. Genet. 38:337-342. https://doi.org/10.1038/ng1743

Somech, R., A. Lev, Y.N. Lee, A.J. Simon, O. Barel, G. Schiby, C. Avivi, I. Barshack, M. Rhodes, J. Yin, et al. 2017. Disruption of Thrombocyte and T Lymphocyte Development by a Mutation in ARPC1B. J. Immunol. 199:4036-4045. https://doi.org/10.4049/jimmunol.1700460

Sommerhoff, C.P. 2001. Mast cell tryptases and airway remodeling. Am. J. Respir. Crit. Care Med. 164(supplement_2):S52-S58. https://doi.org/10 .1164/ajrccm.164.supplement_2.2106058

Spector, S.L., and R.S. Farr. 1976. Atopy reconsidered. Clin. Allergy. 6:83-90. https://doi.org/10.1111/j.1365-2222.1976.tb01416.x

Stepensky, P., B. Keller, M. Buchta, A.K. Kienzler, O. Elpeleg, R. Somech, S. Cohen, I. Shachar, L.A. Miosge, M. Schlesier, et al. 2013. Deficiency of caspase recruitment domain family, member 11 (CARD11), causes profound combined immunodeficiency in human subjects. J. Allergy Clin. Immunol. 131:477-485.el. https://doi.org/10.1016/j.jaci.2012.11.050

Stray-Pedersen, A., P.H. Backe, H.S. Sorte, L. Mørkrid, N.Y. Chokshi, H.C. Erichsen, T. Gambin, K.B. Elgstøen, M. Bjørås, M.W. Wlodarski, et al. Baylor-Johns Hopkins Center for Mendelian Genomics. 2014. PGM3 mutations cause a congenital disorder of glycosylation with severe immunodeficiency and skeletal dysplasia. Am. J. Hum. Genet. 95:96-107. https://doi.org/10.1016/j.ajhg.2014.05.007

Tangye, S.G., B. Pillay, K.L. Randall, D.T. Avery, T.G. Phan, P. Gray, J.B. Ziegler, J.M. Smart, J. Peake, P.D. Arkwright, et al. 2017. Dedicator of cytokinesis 8-deficient $C D 4^{+} \mathrm{T}$ cells are biased to a $\mathrm{T}_{\mathrm{H}} 2$ effector fate at the expense of 
$\mathrm{T}_{\mathrm{H}} 1$ and $\mathrm{T}_{\mathrm{H}} 17$ cells. J. Allergy Clin. Immunol. 139:933-949. https://doi.org/ 10.1016/j.jaci.2016.07.016

Tao, X., C. Grant, S. Constant, and K. Bottomly. 1997. Induction of IL-4-producing CD4+ T cells by antigenic peptides altered for TCR binding. J. Immunol. 158:4237-4244.

Thrasher, A.J., and S.O. Burns. 2010. WASP: a key immunological multitasker. Nat. Rev. Immunol. 10:182-192. https://doi.org/10.1038/nri2724

Torres, J.M., R. Martinez-Barricarte, S. García-Gómez, M.S. Mazariegos, Y. Itan, B. Boisson, R. Rholvarez, A. Jiménez-Reinoso, L. del Pino, R. Rodríguez-Pena, et al. 2014. Inherited BCL10 deficiency impairs hematopoietic and nonhematopoietic immunity. J. Clin. Invest. 124:5239-5248. https://doi.org/10.1172/JCI77493

Tuano, K.S., J.S. Orange, K. Sullivan, C. Cunningham-Rundles, F.A. Bonilla, and C.M. Davis. 2015. Food allergy in patients with primary immunodeficiency diseases: prevalence within the US Immunodeficiency Network (USIDNET). J. Allergy Clin. Immunol. 135:273-275. https://doi.org/ 10.1016/j.jaci.2014.09.024

Turul, T., I. Tezcan, H. Artac, S. de Bruin-Versteeg, B.H. Barendregt, I. Reisli, O. Sanal, J.J. van Dongen, and M. van der Burg. 2009. Clinical heterogeneity can hamper the diagnosis of patients with ZAP70 deficiency. Eur.J. Pediatr. 168:87-93. https://doi.org/10.1007/s00431-008-0718-x

Ui, H., T. Andoh, J.B. Lee, H. Nojima, and Y. Kuraishi. 2006. Potent pruritogenic action of tryptase mediated by PAR-2 receptor and its involvement in anti-pruritic effect of nafamostat mesilate in mice. Eur. J. Pharmacol. 530:172-178. https://doi.org/10.1016/j.ejphar.2005.11.021

Uzel, G., E.P. Sampaio, M.G. Lawrence, A.P. Hsu, M. Hackett, M.J. Dorsey, R.J. Noel, J.W. Verbsky, A.F. Freeman, E. Janssen, et al. 2013. Dominant gain-of-function STAT1 mutations in FOXP3 wild-type immune dysregulation-polyendocrinopathy-enteropathy-X-linked-like syndrome. J. Allergy Clin. Immunol. 131:1611-1623.e3. https://doi.org/10.1016/j.jaci .2012.11.054

Valent, P., C. Akin, and D.D. Metcalfe. 2017. Mastocytosis: 2016 updated WHO classification and novel emerging treatment concepts. Blood. 129:14201427. https://doi.org/10.1182/blood-2016-09-731893

van den Berg, A., A. van Zwol, H.A. Moll, W.P. Fetter, and R.M. van Elburg. 2007. Glutamine-enriched enteral nutrition in very low-birth-weight infants: effect on the incidence of allergic and infectious diseases in the first year of life. Arch. Pediatr. Adolesc. Med. 161:1095-1101. https://doi .org/10.1001/archpedi.161.11.1095

van Panhuys, N., F. Klauschen, and R.N. Germain. 2014. T-cell-receptor-dependent signal intensity dominantly controls $\mathrm{CD} 4(+) \mathrm{T}$ cell polarization In Vivo. Immunity. 41:63-74. https://doi.org/10.1016/j.immuni.2014.06 .003

Villa, A., L.D. Notarangelo, and C.M. Roifman. 2008. Omenn syndrome: inflammation in leaky severe combined immunodeficiency. J. Allergy Clin. Immunol. 122:1082-1086. https://doi.org/10.1016/j.jaci.2008.09 .037

Vissers, J.L., B.C. van Esch, G.A. Hofman, M.L. Kapsenberg, F.R. Weller, and A.J. van Oosterhout. 2004. Allergen immunotherapy induces a suppressive memory response mediated by IL-10 in a mouse asthma model.J. Allergy Clin. Immunol. 113:1204-1210. https://doi.org/10.1016/j.jaci.2004.02.041
Wada, T., S.H. Schurman, E.K. Garabedian, A. Yachie, and F. Candotti. 2005 Analysis of T-cell repertoire diversity in Wiskott-Aldrich syndrome. Blood. 106:3895-3897. https://doi.org/10.1182/blood-2005-06-2336

Wang, Y., C.S. Ma, Y. Ling, A. Bousfiha, Y. Camcioglu, S. Jacquot, K. Payne, E. Crestani, R. Roncagalli, A. Belkadi, et al. 2016. Dual T cell- and B cell-intrinsic deficiency in humans with biallelic RLTPR mutations.J. Exp. Med. 213:2413-2435. https://doi.org/10.1084/jem.20160576

Wesemann, D.R., J.M. Magee, C. Boboila, D.P. Calado, M.P. Gallagher, A.J. Portuguese, J.P. Manis, X. Zhou, M. Recher, K. Rajewsky, et al. 2011. Immature B cells preferentially switch to IgE with increased direct $\mathrm{S} \mu$ to $\mathrm{S} \varepsilon$ recombination.J. Exp. Med. 208:2733-2746. https://doi.org/10.1084/jem .20111155

Wildin, R.S., F. Ramsdell, J. Peake, F. Faravelli, J.L. Casanova, N. Buist, E. Levy-Lahad, M. Mazzella, O. Goulet, L. Perroni, et al. 2001. X-linked neonatal diabetes mellitus, enteropathy and endocrinopathy syndrome is the human equivalent of mouse scurfy. Nat. Genet. 27:18-20. https:// doi.org $/ 10.1038 / 83707$

Wu, G., P.G. Hitchen, M. Panico, S.J. North, M.R. Barbouche, D. Binet, H.R. Morris, A. Dell, and S.M. Haslam. 2016. Glycoproteomic studies of IgE from a novel hyper IgE syndrome linked to PGM3 mutation. Glycoconj. J. 33:447-456. https://doi.org/10.1007/s10719-015-9638-y

Yamane, H., and W.E. Paul. 2013. Early signaling events that underlie fate decisions of naive CD4(+) T cells toward distinct T-helper cell subsets. Immunol. Rev. 252:12-23. https://doi.org/10.1111/imr.12032

Yang, X.P., K. Ghoreschi, S.M. Steward-Tharp, J. Rodriguez-Canales, J. Zhu, J.R. Grainger, K. Hirahara, H.W. Sun, L. Wei, G. Vahedi, et al. 2011. Opposing regulation of the locus encoding IL-17 through direct, reciprocal actions of STAT3 and STAT5. Nat. Immunol. 12:247-254. https://doi.org/10.1038/ ni. 1995

Yu, X., J.R. Almeida, S. Darko, M. van der Burg, S.S. DeRavin, H. Malech, A. Gennery, I. Chinn, M.L. Markert, D.C. Douek, and J.D. Milner. 2014 Human syndromes of immunodeficiency and dysregulation are characterized by distinct defects in T-cell receptor repertoire development. J. Allergy Clin. Immunol. 133:1109-1115.e14. https://doi.org/10.1016/j.jaci .2013 .11 .018

Zhang, Q., J.C. Davis, I.T. Lamborn, A.F. Freeman, H. Jing, A.J. Favreau, H.F. Matthews, J. Davis, M.L. Turner, G. Uzel, et al. 2009. Combined immunodeficiency associated with DOCK8 mutations. N. Engl. J. Med. 361:20462055. https://doi.org/10.1056/NEJMoa0905506

Zhang, Q., C.G. Dove, J.L. Hor, H.M. Murdock, D.M. Strauss-Albee, J.A. Garcia, J.N. Mandl, R.A. Grodick, H. Jing, D.B. Chandler-Brown, et al. 2014a. DOCK8 regulates lymphocyte shape integrity for skin antiviral immunity. J. Exp. Med. 211:2549-2566. https://doi.org/10.1084/jem.20141307

Zhang, Y., X. Yu, M. Ichikawa, J.J. Lyons, S. Datta, I.T. Lamborn, H. Jing, E.S. Kim, M. Biancalana, L.A. Wolfe, et al. 2014b. Autosomal recessive phosphoglucomutase 3 (PGM3) mutations link glycosylation defects to atopy, immune deficiency, autoimmunity, and neurocognitive impairment. $J$. Allergy Clin. Immunol. 133:1400-1409.e5. https://doi.org/10.1016/j.jaci .2014.02.013

Zigmond, S.H. 2000. How WASP regulates actin polymerization. J. Cell Biol. 150:F117-F120. https://doi.org/10.1083/jcb.150.6.F117 